\title{
Antimicrobial Peptides: Versatile Biological Properties
}

\author{
Muthuirulan Pushpanathan, ${ }^{1}$ Paramasamy Gunasekaran, ${ }^{1,2}$ and Jeyaprakash Rajendhran ${ }^{1}$ \\ ${ }^{1}$ Department of Genetics, Centre for Excellence in Genomic Sciences, School of Biological Sciences, Madurai Kamaraj University, \\ Madurai 625 021, India \\ ${ }^{2}$ Thiruvalluvar University, Vellore 632106, India
}

Correspondence should be addressed to Jeyaprakash Rajendhran; jrajendhran@gmail.com

Received 6 March 2013; Revised 4 June 2013; Accepted 9 June 2013

Academic Editor: Severo Salvadori

Copyright (C) 2013 Muthuirulan Pushpanathan et al. This is an open access article distributed under the Creative Commons Attribution License, which permits unrestricted use, distribution, and reproduction in any medium, provided the original work is properly cited.

\begin{abstract}
Antimicrobial peptides are diverse group of biologically active molecules with multidimensional properties. In recent past, a wide variety of AMPs with diverse structures have been reported from different sources such as plants, animals, mammals, and microorganisms. The presence of unusual amino acids and structural motifs in AMPs confers unique structural properties to the peptide that attribute for their specific mode of action. The ability of these active AMPs to act as multifunctional effector molecules such as signalling molecule, immune modulators, mitogen, antitumor, and contraceptive agent makes it an interesting candidate to study every aspect of their structural and biological properties for prophylactic and therapeutic applications. In addition, easy cloning and recombinant expression of AMPs in heterologous plant host systems provided a pipeline for production of disease resistant transgenic plants. Besides these properties, AMPs were also used as drug delivery vectors to deliver cell impermeable drugs to cell interior. The present review focuses on the diversity and broad spectrum antimicrobial activity of AMPs along with its multidimensional properties that could be exploited for the application of these bioactive peptides as a potential and promising drug candidate in pharmaceutical industries.
\end{abstract}

\section{Introduction}

The antimicrobial peptides (AMPs) are biologically active molecules produced by wide variety of organisms as an essential component of their innate immune response. The primary role of the AMPs is host defense by exerting cytotoxicity on the invading pathogenic microorganisms, and they also serve as immune modulators in higher organisms [1]. AMPs are considered as a promising and potential drug candidate for the future due to their broad range of activity, lesser toxicity, and decreased resistance development by the target cells [2]. The AMPs were found to exist in a wide range of secondary structures such as $\alpha$-helices, $\beta$-strands with one or more disulphide bridges, loop and extended structures. The existences of such diverse structural forms of AMPs are highly essential for their broad spectrum antimicrobial activity [3]. Besides these properties, certain crucial factors such as size, charge, hydrophobicity, amphipathic stereo geometry, and peptide self-association to the biological membrane also attributes for their broad spectrum antimicrobial activity. The smaller size of AMPs facilitates the rapid diffusion and secretion of peptide outside the cells, which is required for eliciting immediate defence response against pathogenic microbes [4]. The differences in the lipid composition between prokaryotic and eukaryotic cell membranes represent the targets for AMPs. The antimicrobial specificity of AMPs towards the target cells was highly dependent on the preferential interaction of peptides with the microbial cells, which enable them to kill specific target cells without affecting the host cells [5]. In addition, net charge and hydrophobicity of AMPs play a crucial role in cellular association of these peptides to selective target cellular membranes in exerting antimicrobial activity [6]. AMPs have been reported from different sources such as plants, mammals, insects, marine invertebrates, and environmental libraries (Table 1). Currently, more than 2,000 AMPs have been reported in antimicrobial peptide database (http://aps.unmc.edu/AP/main.php/). Most of them are cationic peptides, and only a few of them are anionic, which shared the ability to fold into amphipathic conformation upon interacting with the membranes [7]. Besides 
TABLE 1: Various sources of AMPs.

\begin{tabular}{|c|c|c|}
\hline Source of AMPs & AMPs & References \\
\hline Insect & $\begin{array}{l}\text { Cecropin A, Sarotoxin IA, ponericin G2, ceratotoxin, stomoxyn, spinigerenin, thanatin, heliomicin, Alo3, } \\
\text { sapecin, defensin A, smD1, gallerimycin, termicin, royalisin, drosomycin, drosocin, metchnikowin, } \\
\text { apidaecin IA, abaecin, formaecin, lebocin, pyrrhocoricin, melittin, attacins, coleoptericin,diptericin, }\end{array}$ & {$[9,10]$} \\
\hline Amphibians & Japonicin-1 \& 2, nigrocin $1 \& 2$, brevinin-20a, temporin-1Od, tigerin-1, pseudin-2, maximin-1, distinctin & [11] \\
\hline Echinoderms & Strongylocins, centrocins, betathymosins, filamin A & [12] \\
\hline Crustaceans & $\begin{array}{l}\text { Callinectin, astacidin 2, armadillidin, homarin, scygonadin, penaeidin, crustin, hyastatin, arasin, stylicin, } \\
\text { hemocyanin derived peptides }\end{array}$ & [13] \\
\hline Plants & Thionins, plant defensins, lipid transfer proteins & [14] \\
\hline Mammals & Defensin, histatin, LL-37, indolicidin, protegrin, lactoferricin & [15] \\
\hline Bacteria & Iturin, bacillomycin, syringomycin, syringostatins, syringotoxins, nikkomycins & [16] \\
\hline Fungi & Echinocandins, aculeacins, mulundocandins, FK463, aureobasidin, leucinostatins, helioferins & [17] \\
\hline Fishes & Pardaxins, misgurin, pleurocidins, parasin, oncorhyncin II and III, chrysophsin and HFIAP & [18] \\
\hline
\end{tabular}

antimicrobial function, AMPs also serve as drug delivery vectors, antitumor agents, mitogenic agents, contraceptive agents, and signalling molecules in signal transduction pathways [8]. This review provide insight into antimicrobials as well as multifunctional properties of AMPs that provides better understanding of versatile biological properties of AMPs for prophylactic and therapeutic application.

\section{Antimicrobial Properties of AMPs}

2.1. Structural Features of AMPS. AMPs are generally defined as peptides of less than 100 amino acid residues with overall net charge of +2 to +9 , represented by positively charged amino acids such as lysine and arginine along with a substantial portion of hydrophobic residues. The structural and physicochemical properties of AMPs play an essential role in determining its specificity towards the target cells. The antimicrobial peptides with different structural forms were listed in Table 2 .

2.1.1. Structural Motifs of AMPs. Antimicrobial peptides have served a fundamental role in evolution of complex multicellular organisms [31]. Insight into the conserved structural elements of AMPs provides information regarding the evolutionary significance of AMPs that serves as template for the design of novel peptide antibiotics [32]. The antimicrobial peptide with proline-arginine-proline (PRP) motif includes proline/arginine-rich cationic peptides, callinectin, and astacidin 2. These peptides contain one or more PRP motif, which showed potent antibacterial activity against Gram-positive and Gram-negative bacteria. Armadillidin is a glycine rich, cationic antimicrobial peptide with unique fivefold repeated motifs of GGGFHR or GGGFHS and amidation at the C-terminal end that displayed potent antibacterial activity against Gram-positive bacteria [33]. Penaeidins are chimeric cationic peptides that consist of PRP motifs at the $\mathrm{N}$-terminal end (PRP-domain) and cysteine rich region at the C-terminal end (cysteine-rich domain) with a conserved chitin binding motif that possessed antimicrobial activity against Gram-positive bacteria and fungi [34]. Crustins are cationic antimicrobial peptides with specific antibacterial activity against Gram-positive bacteria. It possessed a Wap domain at the C-terminal region with eight conserved cysteine residues forming four disulphide core (4DSC), which was highly responsible for protease inhibitory or regulatory mechanisms [35]. Kalata, circulin A \& B and cyclopsychotride are macrocyclic cysteine knot-peptides with endto-end macrocycle and cysteine-knot motif that displayed potent antimicrobial activity against Gram-positive, Gramnegative bacteria, and yeast [36]. Disulphide bridge containing antimicrobial peptides such as HNP-3, mBD-8, phormicin, drosomycin, Ah-AMP-1, MGD-1, protegrin-1, big defensin, gaegurin-1, tachyplesin-1, polyphemusin-1, mytilin A, gomesin, thanatin, and AFP-1 contain conserved GXC or CXG motif ( $\gamma$-core signature) [32]. The AMPs with heparin binding ability contained heparin binding motif such as XBBBXXBX or XBBXBX (where X represents hydrophobic or uncharged amino acids, and $B$ represents basic amino acids). The LL-37 is an amphipathic peptide with helical structure and XBBXBX motifs responsible for heparin binding property [37]. Certain AMPs such as penaeidin, tachystatin, Cy-AMP, Ee-CBP, and MMGP1 contain conserved cysteine residues at the $\mathrm{C}$-terminal ends responsible for chitin binding activity [38].

2.1.2. Structural Requirements and Modification of AMPs. The structural and physicochemical properties of AMPs play an important role in conferring specific toxicity against the target cells. Tachystatin is an antimicrobial peptide identified from the hemocytes of the horseshoe crab, Tachypleus tridentatus, which showed broad spectrum of antimicrobial activity against Gram-positive, Gram-negative bacteria, and fungi. The amphiphilic $\beta$-sheet at the $\mathrm{C}$-terminal end of tachystatin was highly responsible for their cytolytic activity against the target cells [39]. Tenecin 1 is an inducible antibacterial peptide from larvae of Tenebrio molitor, with $\alpha$-helical and $\beta$ sheet fragments at their $\mathrm{C}$-terminal and $\mathrm{N}$-terminal ends that displayed potent antimicrobial activity specifically towards Gram-positive bacteria. The chemical synthesis of truncated peptides revealed that the C-terminal $\beta$-sheet domain of tenecin 1 is highly responsible for both the antifungal and antibacterial activity. The fragment corresponding to $\alpha$ helical region did not show any antimicrobial activity. This might be due to difference in the net positive charge of 
TABLE 2: List of antimicrobial peptides based on their structural features.

\begin{tabular}{|c|c|c|c|c|}
\hline Class of AMP & Structural features & Representative peptides & Structure & References \\
\hline \multirow{9}{*}{ Cationic peptides } & Peptides forming $\alpha$-helical structures & Cecropins & $\alpha$-Helix & [19] \\
\hline & Single disulphide bridge & Thanatin & $\beta$-Sheet & [20] \\
\hline & Two disulphide bridge & Tachyplesin II & $\beta$-Sheet & {$[21]$} \\
\hline & Three disulphide bridge & Penaeidins & $\beta$-Sheet & {$[22]$} \\
\hline & More than three disulphide bridge & Drosomycin & $\alpha \beta$-Structure & {$[20]$} \\
\hline & Proline-rich peptide & Pyrrhocoricin & $\alpha \beta$-Structure & [23] \\
\hline & Glycine-rich peptide & Diptericins & - & {$[24]$} \\
\hline & Histidine-rich peptide & Histatin & Rich in $\mathrm{H}$ & {$[25]$} \\
\hline & Tryptophan-rich peptide & Indolicidin & Extended & [26] \\
\hline \multirow{4}{*}{ Noncationic peptides } & Neuropeptide derived molecules & Secretolytin & $\alpha$-Helix & [27] \\
\hline & Aspartic acid rich peptides & Dermcidin & - & {$[28]$} \\
\hline & Aromatic dipeptides & $\begin{array}{l}\text { N-Alanyl-5-s-glutathionyl- } \\
\text { 3,4 Dihydroxy-phenylalanine and p-hydroxy } \\
\text { cinnamaldehyde }\end{array}$ & - & [29] \\
\hline & Oxygen binding proteins & Lactoferricin & $\beta$-Turn & [30] \\
\hline
\end{tabular}

both $\alpha$-helical $(+1)$ and $\beta$-sheet region $(+5)$ [40]. Thanatin is an inducible antimicrobial peptide reported from the insect Podisus maculiventris with a broad spectrum of antimicrobial activity against Gram-positive, Gram-negative bacteria, and fungi. The mechanism of action of thanatin involved binding of peptide to the target cell membrane and thereby reduced the surface charge density of lipopolysaccharide and the electrostatic repulsion between the cells, which cause rapid aggregation of target cells and cell death [41]. Unlike antibacterial peptides, no conserved structural domains have been reported for antifungal peptides. Most of the antifungal peptides have been reported with chitin and heparin binding abilities [41]. The antimicrobial peptides entered the cells through energy dependent or energy independent mechanisms. The AMPs rich in positively charged amino acids such as arginine and lysine induced energy dependent endocytic pathway such as macropinocytosis for entering into the cells, whereas other AMPs such as MMGP1 and maganin entered the cells through energy independent direct cell-penetration mechanism, which does not require ATP [42-44].

Most of the naturally occurring AMPs are not optimised for efficient activity and need to be improved through different strategies, before it could be used as therapeutics. Recently, several methods have been tested using the native templates to generate more efficient AMPs such as random mutagenesis, quantitative structure-activity relationship (QSAR), altering the peptide structures by cyclization, or by increasing the charge or hydrophobicity of the peptide by tagging. Random mutagenesis involved methods that modify the naturally existing AMPs by addition/deletion/replacement of single or more residues or truncation at the $\mathrm{N}$ - or C-terminal or generation of chimeric peptides by combination of both methods [56]. QSAR provides a working conceptual model of bioactive peptides, which attempt to find consistent relationship between biological activity and molecular properties. AMPs based QSAR studies involve limited set of systemic modification of residues in naturally occurring AMPs to form peptides with amphipathic structures. In this, a few aminoacids with specific characteristics such as basic (lysine or arginine) or hydrophobic amino acids (alanine, leucine, phenylalanine or tryptophan) are used to obtain peptide with maximum activity and minimum toxicity towards the host [57]. Further, the chemical attachment of aliphatic acids to the $\mathrm{N}$-terminus of biologically inactive peptides with different lengths $(10,12,14$, and $16 \mathrm{aa})$ resulted in generation of lipopeptides with lytic activity. The selectivity of these lipopeptides against bacteria, fungi, and human erythrocytes was influenced by the length of fatty acids chain, which attributed for increased antimicrobial activity and resistance to proteases [58]. In addition, chemically induced cross links or introduction of covalent lactam bonds in AMPs provided a way for introducing conformational constraint in peptides that confer newer properties to AMPs. The formation of covalent cross link between Trp 6 and Trp 9 in synthetic indolicidin analogue showed decreased susceptibility to protease. Similarly, the formation of covalent lactam bond between cecropin-melittin hybrid peptide improved its antibacterial activity [59]. The antimicrobial activity of AMPs could also be enhanced through modification of their existing structural forms by manipulating the hydrophobicity or flexibility of the peptide secondary structures. The antimicrobial activity of antibacterial peptide, indolicidin isolated from bovine neutrophils was increased by bringing the C-termini and $\mathrm{N}$-termini regions of peptide closer to each other, and the modified peptide was stabilized with disulphide bond by introducing cysteine residues at both the ends, which showed enhanced antibacterial activity against Gram-negative bacteria $[60]$.

2.1.3. AMPs with Unusual Amino Acids. Many AMPs have unusual amino acids and hence have unusual structures, which attributed for wide range of bioactivities (Figure 1 and Table 3). Depsipeptides are nonribosomal peptides characterized by one or more of the amide (-CONHR-) bonds 
TABLE 3: List of antimicrobial peptides with unusual amino acids.

\begin{tabular}{|c|c|c|c|c|c|}
\hline Peptide & Source & Activity & Organisms & Unusual amino acids & References \\
\hline Discodermin A & $\begin{array}{l}\text { Discodermia kiiensis } \\
\quad \text { (sponge) }\end{array}$ & Antifungal & C. albicans & $\begin{array}{l}\text { Tert-leucine (t-Leu), cystenoic acid, and } \\
\text { sarcosine }\end{array}$ & {$[45]$} \\
\hline Jaspamide & Jaspis sp. (sponge) & Antifungal & C. albicans & $\begin{array}{l}N \text {-Methyl-2-bromo-D-tryptophan (Me-BrTrp) } \\
\text { and L- } \beta \text {-tyrosine (L- } \beta \text { Tyr) }\end{array}$ & {$[46]$} \\
\hline Theonellamide F & Theonella sp (sponge) & Antifungal & C. albicans & $\begin{array}{l}\text { histidinoalanine, } \\
\text { 3-Methyl-p-bromophenylalanine, } \\
(2 S, 4 R) \text {-2-amino-4-hydroxyadipic acid } \\
\text { (L-Ahad), and } \\
(3 S, 4 S, 5 E, 7 E) \text {-3-amino-4-hydroxy-6-methyl-8- } \\
\text { ( } p \text {-bromophenyl)-5,7-octadienoic } \\
\text { acid }\end{array}$ & {$[45]$} \\
\hline Cyclolithistide A & T. swinhoei (sponge) & Antifungal & C. albicans & $\begin{array}{l}\text { 4-Chloroisoleucine (C1-Ile), 2-amino-pentanoic } \\
\text { acid (D-Ape) and } \\
\text { 4-amino-3,5-dihydroxyhexanoic acid (Adha) }\end{array}$ & {$[47]$} \\
\hline Microsclerodermin A & Theonella sp. (sponge) & Antifungal & C. albicans & $\begin{array}{l}(2 S, 3 R, 4 S, 5 S, 6 S, 11 E) \text {-3-amino-6-methyl-12-( } p \text { - } \\
\text { Methoxyphenyl)-2,4,5-trihydroxydodec-11-enoic } \\
\text { acid (AMMTD), } \\
\text { (3R)-4-amino-3-hydroxylbutyric acid (GABOB), } \\
\text { and 3-hydroxy-4-amino-5-vinylpyrrolidone. }\end{array}$ & {$[48]$} \\
\hline Callipeltin A & Callipelta sp. (sponge) & $\begin{array}{l}\text { Antifungal } \\
\text { Antiviral }\end{array}$ & $\begin{array}{l}\text { C. albicans, } \\
\text { HIV }\end{array}$ & $\begin{array}{l}(2 R, 3 R, 4 S)-4-\text { Amino-7-guanidino-2,3- } \\
\text { dihydroxyheptanoic acid } \\
(\text { AGDHE) }\end{array}$ & [49] \\
\hline Dolastatin 10 & $\begin{array}{l}\text { Dolabella auricularia } \\
\text { (sea hare), } \\
\text { Gymnangium regae } \\
\text { (Marine hydroid) }\end{array}$ & Antifungal & $\begin{array}{l}\text { Cryptococcus } \\
\text { neoformans }\end{array}$ & $\begin{array}{l}\text { O-demethyldolaproline (Ddap), } \\
N \text {-desmethyldolaisoleucine (Ddil), } \\
\text { L-threo-phenylserine (L-Pser), and L-guanidino } \\
\text { serine (Gser). }\end{array}$ & {$[50]$} \\
\hline Nukacin ISK-1 & $\begin{array}{l}\text { Staphylococcus warneri } \\
\text { ISK-1 }\end{array}$ & Antibacterial & $\begin{array}{l}\text { Gram- } \\
\text { positive } \\
\text { bacteria }\end{array}$ & $\begin{array}{l}\text { Lanthionine, 3-methyllanthionine, and } \\
\text { dehydrobutyrine }\end{array}$ & {$[51]$} \\
\hline Mersacidin & Bacillus subtilis & Antibacterial & $\begin{array}{l}\text { Gram- } \\
\text { positive } \\
\text { bacteria }\end{array}$ & Lanthionine or 3-methyllanthionine & {$[52]$} \\
\hline Microbisporicin & Microbispora sp & Antibacterial & $\begin{array}{l}\text { Gram- } \\
\text { positive } \\
\text { bacteria }\end{array}$ & $\begin{array}{l}\text { 5-Chloro-trypthopan and mono- (in A2) or } \\
\text { bis-hydroxylated (in A1) proline }\end{array}$ & {$[53]$} \\
\hline lacticin 3147 & Lactococcus lactis & Antibacterial & $\begin{array}{l}\text { Gram- } \\
\text { positive } \\
\text { bacteria }\end{array}$ & Lanthionine or $\beta$-methyllanthionine & {$[54]$} \\
\hline Planosporicin & Planomonospora sp & Antibacterial & $\begin{array}{l}\text { Gram- } \\
\text { positive } \\
\text { bacteria }\end{array}$ & Lanthionine and methyllanthionine & {$[53]$} \\
\hline Nisin & Lactococcus lactis & Antibacterial & $\begin{array}{l}\text { Gram- } \\
\text { positive } \\
\text { bacteria }\end{array}$ & $\begin{array}{l}\text { Lanthionine methyllanthionine } \\
\text { didehydroalanine didehydroaminobutyric acid }\end{array}$ & [55] \\
\hline
\end{tabular}

replaced by an ester bonds (COOR). Depsipeptides also contained organic acids in addition to amino acids. Examples for depsipeptides include discodermin A, jaspamide, theonellamide F, cyclolithistide A, callipeltin A, dolastatin 10, and theonegramide [61]. Lantibiotics are ribosomal synthesized antibacterial peptides produced by some Gram-positive bacteria and are characterized by the presence of unusual amino acids such as lanthionine and dehydrated amino acid dehydroalanine and 2-aminoisobutyric acid, which includes nukacin ISK-1, mersacidin, microbisporicin, lacticin 3147, planosporicin, and nisin [62].
2.2. Mechanisms of Action of AMPs. AMPs have attained dynamic interchange in their structure and topologies upon interacting with the microbial cell membranes [63]. The outer surface of prokaryotic cell is negatively charged due to the presence of lipopolysaccharides or teichoic acid, whereas the outer leaflet of eukaryotic cell is composed of zwitterionic phosphatidylcholine and sphingomyelin phospholipids [64]. The electrostatic interaction of peptides with the negatively charged molecules on the membrane seems to be the primary mechanism for antimicrobial activity. In other cases, AMPs exert antimicrobial activity in target cells by 


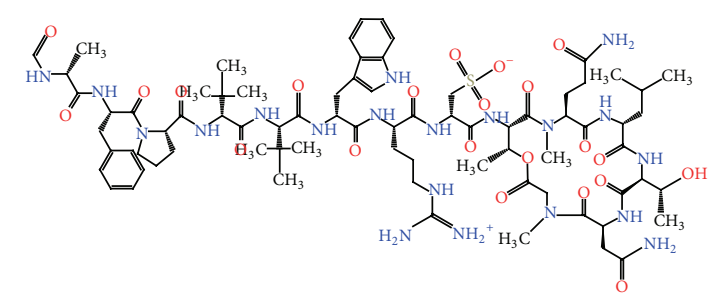

Discodermin A

$\left(\mathrm{C}_{77} \mathrm{H}_{116} \mathrm{~N}_{20} \mathrm{O}_{22} \mathrm{~S}\right)$

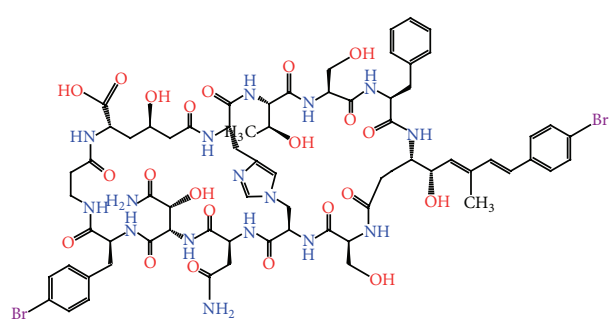

Theonellamide $\mathrm{F}$

$\left(\mathrm{C}_{69} \mathrm{H}_{86} \mathrm{Br}_{2} \mathrm{~N}_{16} \mathrm{O}_{22}\right)$

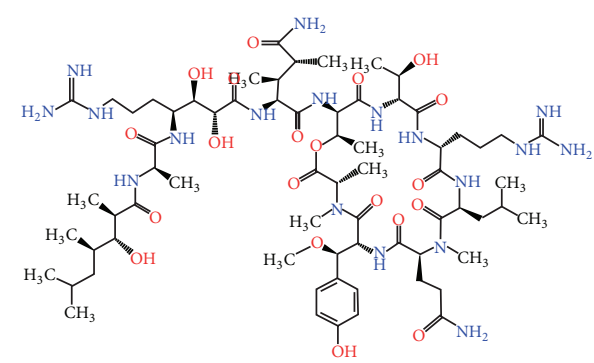

$\underset{\left(\mathrm{C}_{68} \mathrm{H}_{116} \mathrm{~N}_{18} \mathrm{O}_{20}\right)}{\text { Callipeltin A }}$

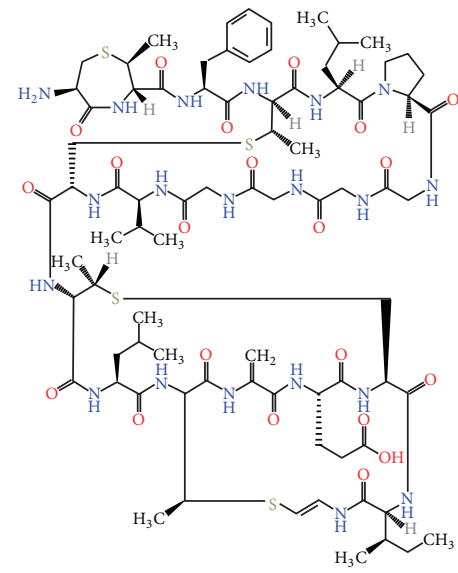

Mersacidin

$\left(\mathrm{C}_{80} \mathrm{H}_{120} \mathrm{~N}_{20} \mathrm{O}_{21} \mathrm{~S}_{4}\right)$

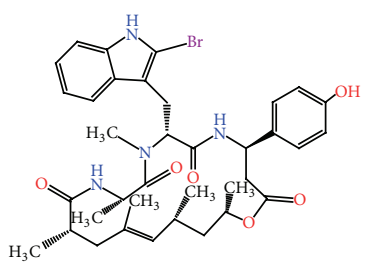

Jaspamide
$\left(\mathrm{C}_{36} \mathrm{H}_{45} \mathrm{Br} \mathrm{N}_{4} \mathrm{O}_{6}\right)$

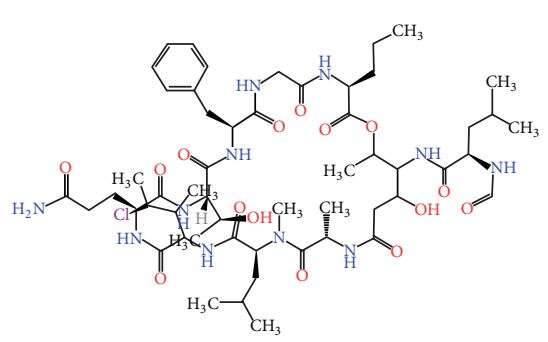

Cyclolithistide A

$\left(\mathrm{C}_{54} \mathrm{H}_{86} \mathrm{Cl} \mathrm{N}_{11} \mathrm{O}_{15}\right)$

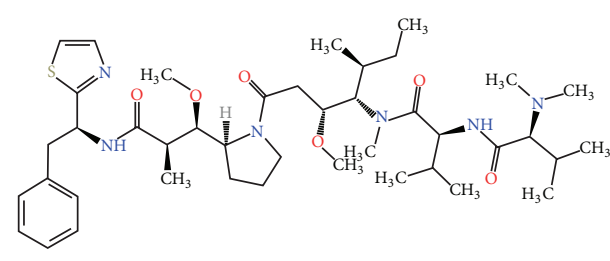

Dolastatin 10

$\left(\mathrm{C}_{42} \mathrm{H}_{68} \mathrm{~N}_{6} \mathrm{O}_{6} \mathrm{~S}\right)$

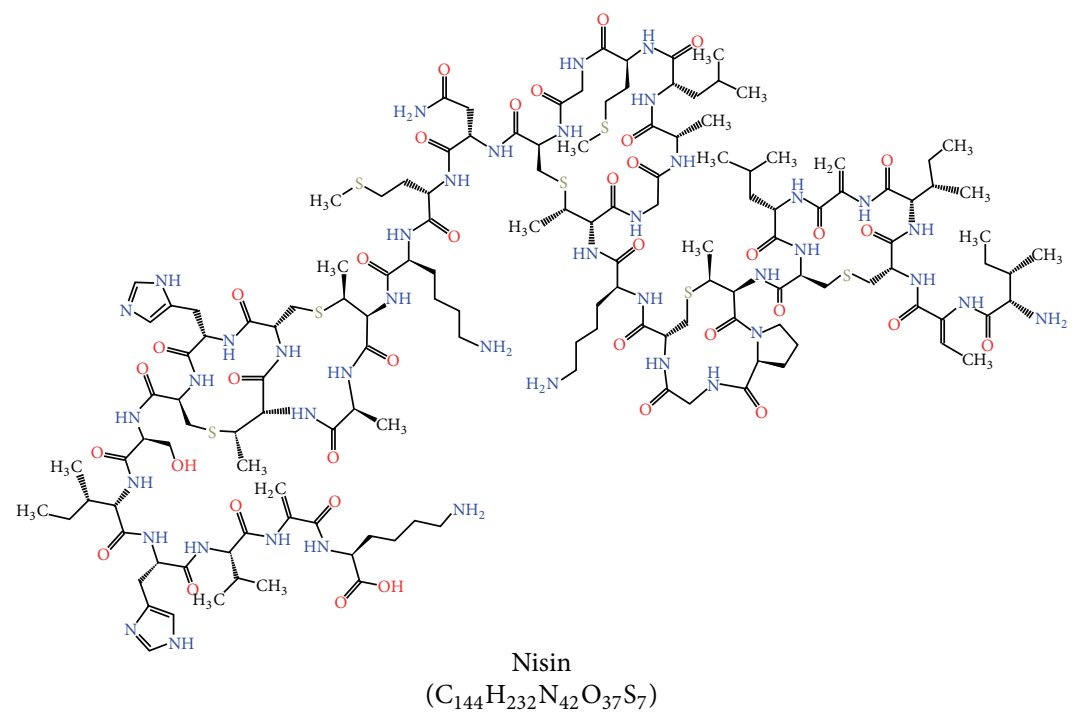

FIGURE 1: Representative chemical structure of AMPs with unusual amino acids. 


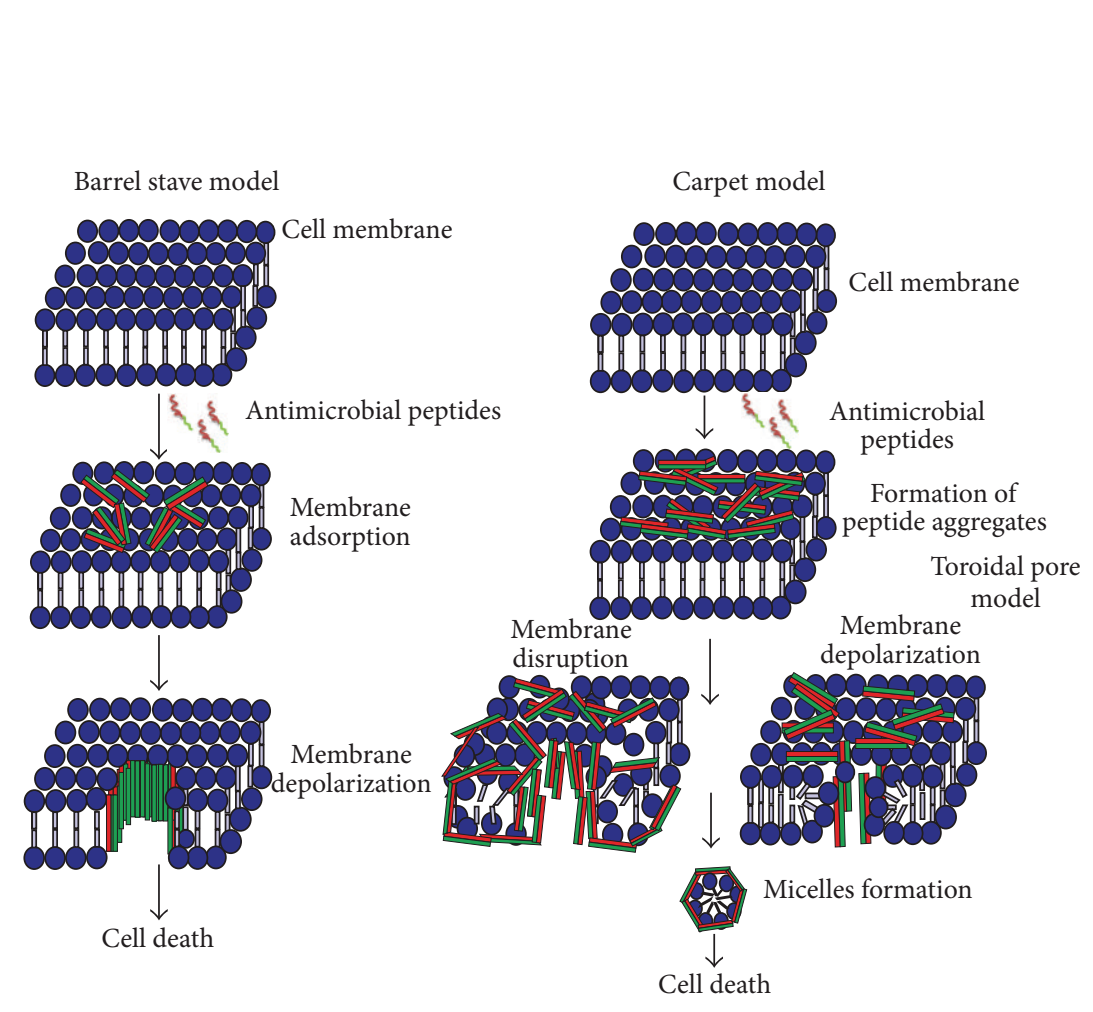

(a) ATP independent mechanisms
Macropinocytosis

Cell membrane
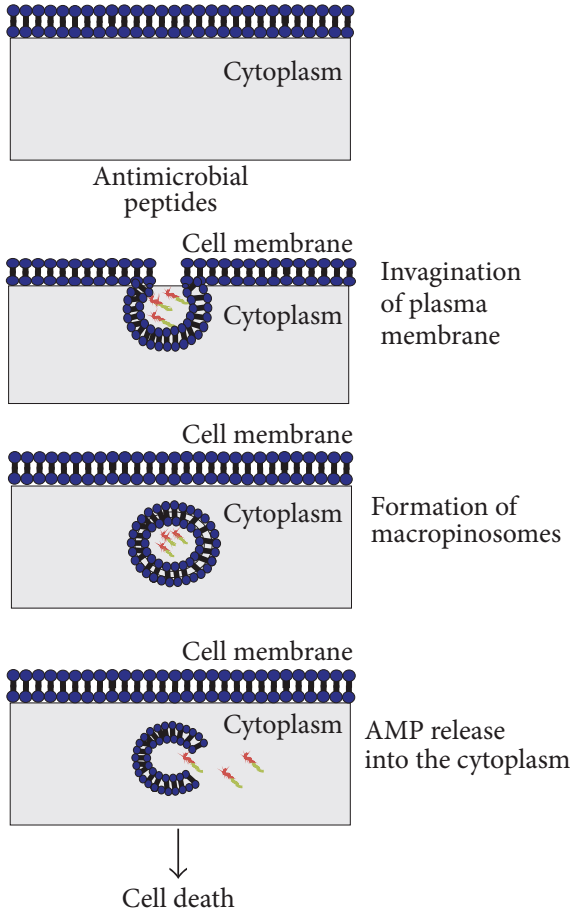

(b) ATP dependent mechanism

Figure 2: Proposed mechanisms of actions of AMPs. (a) Energy independent mechanism: it includes barrel stave model, carpet model, and toroidal pore model. (b) Energy dependent mechanism: it includes macropinocytosis.

translocating across the cell membrane and inhibit essential cellular processes such as protein synthesis, nucleic acid synthesis, enzymatic activities, and cell wall synthesis [7]. Certain other factors such as magnitude and charge of the outer membrane, the concentration of negatively charged molecules, molecular architecture, and fluidity of the outer membrane were also essential for the transport of peptide across the membrane [65]. The fluidity of the membrane was found to regulate the adsorption and insertion of AMPs into the biological membrane. Based on the mechanisms of action, antimicrobial peptides are broadly categorized into membrane acting and nonmembrane acting peptides. Membrane permeabilizing peptides are mostly represented by cationic peptides capable of forming transient pores on the membrane, whereas nonmembrane permeabilizing peptides have the ability to translocate across the cell membrane without permeabilizing the membrane. Certain antibacterial peptides forming transmembrane pores on the target cell membrane include defensin [66], melittin [67], magainins [68], and LL37 [69]. Antimicrobial peptides such as buforin II [44], dermaseptin [70], HNP-1 [71], pleurocidin [70], indolicidin [26], pyrrhocidin [23], and mersacidin [52] get translocated across the cell membrane and inhibit essential cellular processes that lead to cell death. Certain antifungal peptides such as papiliocin [72], melittin [73] histatin [74], and lactoferrin [70] exert their antimicrobial action through formation of reactive oxygen species.
AMPs promote membrane damage in target cells either by membrane thinning or by pores formation or by lipid bilayer disruption [75]. Several models have been proposed to describe the mechanism of action of antimicrobial peptides. The cellular uptake mechanisms of AMPs are categorized into energy dependent and energy independent uptake mechanisms (Figure 2). Energy independent uptake mechanisms include barrel-stave model, carpet model, or toroidal model, and energy dependent uptake mechanism includes macropinocytosis. In barrel-stave mechanism, the peptide monomers get aggregated on the surface of the membrane. The aggregated peptides get inserted into the membrane and orient themselves in such a way that their nonpolar side chains direct the hydrophobic lipid core of the membrane, and the hydrophilic surfaces of peptides point inward and formed water filled transmembrane pore that caused release of intracellular content and consequent cell death. An example for antimicrobial peptides that follows barrelstave mechanisms includes alamethicin and gramicidin $\mathrm{S}$ [76-78]. In carpet model, the peptides initially get associated on the surface of the membrane and form a local carpet. Once particular threshold concentration was reached, the peptide induced membrane permeation that leads to disruption of cell membrane and causes lysis of the microbial cells [79]. In toroidal pore model, the aggregated peptides either prior or after binding with the membrane surfaces induced membrane depolarization and form a toroidal shaped 
transmembrane pores with micellar formation that leads to cell death [80]. Macropinocytosis is the energy independent uptake route of AMPs, in which the plasma membrane of the target cells folds inward along with the peptide and forms vesicles called macropinosomes. Subsequently, the AMPs within the vesicles get released into the cytoplasm and exert their antimicrobial action [81].

\section{Multidimensional Properties of AMPs}

3.1. AMPs As Drug Delivery Vector. Nonlytic cell-penetrating AMPs were used as drug delivery vector to treat and manage several diseases. Certain large hydrophilic drugs cannot easily penetrate through the cell membrane barriers. In such cases, AMPs with efficient membrane translocating property, which could enter the cells without causing damage to the membranes, were used as drug delivery vectors [82]. The main feature of AMPs to serve as delivery vector is that they should be able to penetrate the cell membrane at very low concentrations (micromolar) without any specific receptors and capable of efficiently delivering electrostatically or covalently bound biologically active cargoes such as drugs into the cell interior [83]. Antibacterial peptides such as LL-37, TP10, and pVEC were associated with bacterial membrane damage shown to act as cell penetrating peptides (CPPs) without exhibiting toxicity to eukaryotic host cells $[84,85]$. Representative analogue of antimicrobial peptides magainin 2 and buforin 2 was found to enter the human carcinoma cells through membrane translocating mechanisms. The translocation of magainin 2 analogue required transient pore formation as an intermediate steps, which showed higher toxicity to the carcinoma cells, whereas buforin 2 analogue translocated across the membrane in a less concentration dependent passive mechanism without causing significant toxicity to carcinoma cells [86]. SynB vectors are new family of peptide vectors derived from an antimicrobial peptide protegrin-1 (PG-1), lacking the cysteine residues responsible for membrane disrupting activity in protegrin-1. SynB vectors are capable of transporting very large molecules such as streptavidin (MW: $60 \mathrm{kDa}$ ) and IgGs (MW: $150 \mathrm{kDa}$ ) and were used to deliver drugs efficiently into complex biological membranes such as blood-brain barrier [87]. Pyrrhocoricin and Bac7 are cell-penetrating antimicrobial peptides that translocate across the cell membrane through binding of receptors $[88,89]$. Certain antimicrobial peptides such as tat, penetratin, pep1, and MMGP1 were reported to enter the target cells through energy independent direct cell-penetration mechanisms $[43,90]$.

3.2. Tumoricidal and Mitogenic Properties of AMPs. The ability of AMPs to interact with different cell membranes makes it to serve as the multifunctional effector molecules (Figure 3). Increased susceptibility of tumour cells to cationic membrane active AMPs due to the presence of high content of anionic phosphatidylserine molecules on their membranes than the normal cells makes it an interesting candidate to use AMPs as antitumour agents [110]. The selected AMPs with tumoricidal properties are listed in Table 4. AMPs such as magainins [111], defensins [112], BMAP-27 and BMAP-28 [113], gaegurins

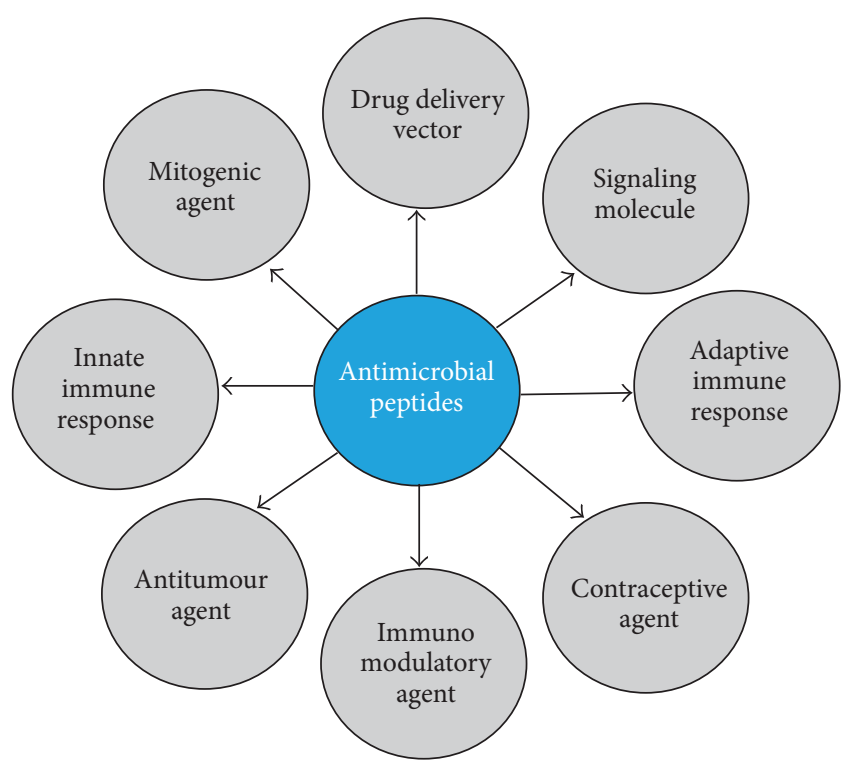

FIGURE 3: Schematic representation of multifunctional properties of antimicrobial peptides.

[114], tachyplesin I [115], cecropins, and melittin [99] were reported to exhibit tumoricidal activity against melanoma and carcinoma cells both under in vitro and in vivo conditions. Generally higher concentration of AMPs is required to achieve tumoricidal activity. For instance, magainin II (MG2) exhibited cytotoxicity in tumour cells only at higher concentration, likely due to the inefficiency of MG2 in cell membrane binding and its subsequent entry. Conjugation of CPP penetratin (Antp) to MG2 showed enhanced cytotoxicity to tumour cells at a lesser concentration [116]. Furthermore, AMPs are more susceptible to degradation by proteases in the extracellular matrix of the tumour cells, which leads to loss in their tumoricidal activity. This could be overcome by expression of AMP encoding gene directly into the tumour cells or by replacement of peptide amino acids by their $\mathrm{D}$-amino acids and modification of peptide terminal by amidation [117]. Recent synthesis of truncated fragments of antibacterial peptides such as epinecidin-8 and pardaxin- 6 showed higher tumoricidal activity against human epithelial carcinoma (HeLa) and fibrosarcoma (HT1080) cell lines [118]. The combination of cell-penetrating- $\gamma$ peptide, PEG-1, with antimicrobial undecapeptides showed efficient anticancer properties against MDA-MB-231 human breast cancer cells [119]. Certain AMPs such as pexiganan MSI-78, citropin 1.1, protegrin 1, synthetic lipopeptide, and $\mathrm{N}$ - $\alpha$-palmitoyl-L-lysine-L-lysine amide (Pal-Lys-Lys- $\mathrm{NH}_{2}$ ) showed cytotoxic activity against U937 histiocytic cell line. Of these, pexiganan MSI-78, protegrin 1, and lipopeptide showed increased tumoricidal activity due to their stronger membranolytic activity that leads to necrosis [120]. Cecropins $\mathrm{A}$ and $\mathrm{B}$ showed selective inhibitory and antiproliferative efficacy against bladder tumour cells lines, RT4, 647V, J82, 486P, and benign fibroblast cell line, 3T6 [101]. Defensin stimulated the growth of normal fibroblast and epithelial cell under in vitro conditions, which was highly essential for 
TABLE 4: List of antimicrobial peptides with antitumour activity.

\begin{tabular}{|c|c|c|c|}
\hline AMP & No. of amino acids & Susceptible cancer cells & References \\
\hline Pardaxin & 33 & Murine fibrosarcoma & [91] \\
\hline Dermaseptin B2 & 33 & Prostate adenocarcinoma cell line PC3 & [92] \\
\hline Magainins & 21 to 27 & HL-60 human promyelocytic leukemia cells, human lung carcinoma cells & [93] \\
\hline Gaegurins & 24 & HCT116 colon and MCF-7 breast carcinoma cells & {$[86]$} \\
\hline Melittin & 26 & $\begin{array}{l}\text { U937 human monocytic leukemia cells, Du145 prostate carcinoma cells, SKOV3 ovarian } \\
\text { carcinoma cells, B16 murine melanoma cells, BEL-7402 human hepatocellular carcinoma } \\
\text { cells }\end{array}$ & {$[94,95]$} \\
\hline LL-37 & & Human oral squamous carcinoma cells, KB human squamous cancer cell lines & [96] \\
\hline Cecropins & $24-39$ & $\begin{array}{l}\text { HL-60 human promyelocytic leukemia cells, CCRF-SB human lymphoblastic leukemia } \\
\text { cells, EJ human bladder carcinoma cells, ascitic colon adenocarcinoma cells, bladder } \\
\text { tumour cells lines, RT4, 647V, J82, 486P and benign fibroblast cell line, 3T6 }\end{array}$ & {$[97-101]$} \\
\hline $\begin{array}{l}\text { BMAP-27, } \\
\text { BMAP-28 }\end{array}$ & 27,28 & $\begin{array}{l}\text { Human leukemia cells, CEM-CCRF human T leukemia cells, U937 and K562 human } \\
\text { leukemia cell lines }\end{array}$ & {$[102]$} \\
\hline Defensins & 29 to 45 & $\begin{array}{l}\text { Raji human B-lymphoma cells, human oral squamous carcinoma cells, MOT mouse } \\
\text { teratocarcinoma cells, fibroblast and epithelial cells }\end{array}$ & {$[103,104]$} \\
\hline $\begin{array}{l}\text { Lactoferricin } \\
\text { (Lfcin B) }\end{array}$ & 25 & Human leukemia and breast carcinoma cells, human endothelial cells & {$[105,106]$} \\
\hline Tachyplesin I & 17 & $\begin{array}{l}\text { Human TSU prostate carcinoma cells, endothelial cells, B16 melanoma cells, SMMC-7721 } \\
\text { human hepatoma cells, BGC- } 83 \text { human gastric adenocarcinoma cells. }\end{array}$ & [107] \\
\hline PR-39 & 39 & Human hepatocellular carcinoma cell lines & {$[108]$} \\
\hline $\begin{array}{l}\text { Cecropin- } \\
\text { Melittin } \\
\text { (CA-ME) }\end{array}$ & 20 & Human small cell lung cancer cell line & [109] \\
\hline $\begin{array}{l}\text { Cecropin- } \\
\text { Magainin } \\
\text { (CA-MA) }\end{array}$ & 20 & Jurkat T leukemia cells, K562 chronic myeloid leukemia cells & {$[55]$} \\
\hline
\end{tabular}

the healing wounds under in vivo conditions. Dermaseptin (Drs) B2 is an AMP identified from the skin secretion of the Amazonian tree frog; Phyllomedusa bicolor had both antitumour and angiostatic activities against prostate adenocarcinoma cell line, PC3 in a xenograft model in vivo [92]. These functional dualism of AMPs to act as antitumor and mitogenic agent makes it an interesting candidate to study every aspect is of their biological activity for clinical applications.

3.3. AMPs As Signalling Molecules. Host defense peptides (HDPs) are short cationic AMPs produced by the immune systems of most organisms, which plays a crucial role in innate immunity [127]. Most HDPs are involved in modulation of immune response as host defense and also act as modulators of signal transduction pathways by influencing the activity of intracellular signalling targets such as protein kinases (Table 5). Defensins are HDPs produced by different cell types such as lymphocytes, neutrophils, tissue macrophages, small intestinal epithelial cells, keratinocytes, and cardiomyocytes and are classified into two groups such as $\alpha$-defensins and $\beta$-defensins. Defensins were known to involve in host cell receptor interaction, chemo attractant of immune cells, recruitment of neutrophils, mobilization of immunocompetent T-cells as well as enhancer of cell adhesion, and activation of classical complement pathways [129133]. Especially, murine defensins regulate the migration and recruitment of antigen presenting and immunocompetent cells by binding with CC-chemokine receptors during inflammatory and immunological responses. Guinea pig defensins induced adhesion of neutrophils and inhibit generation of superoxide anion during phagocytosis of complementopsonized particle [134]. LL-37 is a host defense AMP produced by different cell types such as neutrophils, mast cells, monocytes, and macrophages that serve as a chemoattractant of neutrophils and mast cells, inhibit neutrophil and keratinocytes apoptosis, promote chemokine induction, angiogenesis, and stimulate differentiation of monocytes and proliferation of vascular endothelium. In addition, it also exhibits anti-inflammatory and antiendotoxic effects [127]. PR-39 is a proline and arginine rich antimicrobial peptide isolated from pig intestine, which regulate various processes such as cell development, cell proliferation, cell cycle control, cell survival, migration, and invasion by binding with the Cas family adapter protein, p130 [135]. Besides antimicrobial and immune regulating action, AMPs play a key role in immune neuroendocrine interactions, taking part in the pathogenesis of stress reactions (corticostatic action) and also serve as regulatory peptides of adaptogenic action [136]. The epidermoid carcinoma-derived antimicrobial peptide (ECAP) — inhibits autophosphorylation of epidermal growth factor receptor and leads to decreased activity of Lyn and Syk tyrosine kinases [126]. AMPs at their subinhibitory concentrations activate numerous genes involved in signal transduction 
TABLE 5: List of antimicrobial peptides as signalling molecules.

\begin{tabular}{|c|c|c|c|c|}
\hline AMP & Source & Location & Function as signalling molecule & References \\
\hline $\begin{array}{l}\text { Human neutrophil } \\
\text { peptides (HNP-1, } \\
\text { HNP-2, and HNP-3) }\end{array}$ & Human & $\begin{array}{l}\text { Bone marrow cells, } \\
\text { peripheral leukocytes }\end{array}$ & $\begin{array}{c}\text { Inhibitor of phospholipid/Ca }{ }^{2+} \text { protein kinase } \\
(\mathrm{PKC}) \text {, phosphorylation of endogenous } \\
\text { proteins, chemo attractant of monocytes, } \\
\text { stimulate release of cytokines (IL-1 and IL-8) } \\
\text { and TNF }\end{array}$ & {$[121]$} \\
\hline Beta defensins & $\begin{array}{l}\text { Human, rabbit, } \\
\text { guinea pig }\end{array}$ & $\begin{array}{l}\text { Epithelial cells lining } \\
\text { various organs such as } \\
\text { epidermis, bronchial } \\
\text { tree, and genitourinary } \\
\text { tract }\end{array}$ & $\begin{array}{l}\text { Induce release of histamine and prostaglandin } \\
2 \text { by activation and degranulation of mast cells }\end{array}$ & {$[122]$} \\
\hline CAP37 & Human & $\begin{array}{c}\text { Polymorphonuclear } \\
\text { leukocytes (PMNs), } \\
\text { platelets, ocular epithelia }\end{array}$ & $\begin{array}{c}\text { Chemotactic attractant for monocytes, binds } \\
\text { heparin and LPS, induce leukocyte adhesion to } \\
\text { endothelial cells, upregulate adhesion } \\
\text { molecules, involved in leukocyte epithelial and } \\
\text { epithelial extracellular matrix interactions, } \\
\text { Upregulation of phospholipid/Ca }{ }^{2+} \text { protein } \\
\text { kinase (PKC) }\end{array}$ & {$[123]$} \\
\hline PR-39 & Pig & Intestine & $\begin{array}{l}\text { Inhibit ubiquitin-proteasome-dependent } \\
\text { degradation of hypoxia-inducible factor- } 1 \alpha \\
\text { protein and induce angiogenesis, binds with cas } \\
\text { protein and regulates cell adhesion, migration } \\
\text { and transformation, inhibit P13-kinase activity, }\end{array}$ & {$[124,125]$} \\
\hline $\begin{array}{l}\text { Epidermoid } \\
\text { carcinoma-derived } \\
\text { antimicrobial peptide } \\
\text { (ECAP) }\end{array}$ & Human & Tumour cells & $\begin{array}{l}\text { Inhibit EGFR auto phosphorylation and leads } \\
\text { to decreased activity of nonreceptor protein } \\
\text { kinases belonging to different families such } \\
\text { Syk, Lyn and PKCmu }\end{array}$ & {$[126]$} \\
\hline LL-37 & Human & $\begin{array}{l}\text { Conjunctival and } \\
\text { corneal epithelial cells }\end{array}$ & $\begin{array}{c}\text { Chemotactic for monocytes, T-cells, } \\
\text { neutrophils and mast cells, stimulate } \\
\text { angiogenesis, stimulates IL- } 8 \text { secretion, } \\
\text { modulate dendritic cells differentiation, } \\
\text { activator of extracytoplasmic function (ECF) } \\
\text { sigma factors and regulates stress tolerance, } \\
\text { keratinocytes apoptosis, anti-inflammatory and } \\
\text { antiendotoxic effects }\end{array}$ & {$[123,127]$} \\
\hline Protegrin-1 (PG-1) & Porcine & Leukocytes & $\begin{array}{l}\text { Activator of extracytoplasmic function (ECF) } \\
\text { sigma factors and regulates stress tolerance }\end{array}$ & {$[128]$} \\
\hline
\end{tabular}

pathways. Sigma factors are an essential component of RNA polymerases and determine the selectivity of promoter. The substitution of one sigma factor for another can redirect RNA polymerases in a cell to activate the transcription of genes. The extra cytoplasmic function (ECF) sigma factors are small regulatory proteins that are quite divergent in sequence relative to most other sigma factors, and they function as antisigma factors that bind and inhibit cognate sigma factor upon receiving a stimulus from the environment [137] Naturally-derived AMP such as LL-37 and PG-1 serves as an activator of ECF sigma factors regulons such as SigW and SigM in a weak manner, whereas their synthetic analogue poly-L-lysine seems to be the strong activator of SigW [128]. SigM is required for maintaining the integrity of the cell envelope during stress induced by antibiotics, ethanol, heat, acids, and superoxides. It is also essential for the cells to survive under high salt concentrations [138, 139]. SigW is activated on stress induced by alkaline shock, inhibition of cell wall synthesis, disruption of membrane integrity by detergents $[140,141]$. Certain immunomodulatory anti-infectives with antimicrobial properties in commercial development are CD-NP, a chimeric synthetic peptide NP (37 mer) used for the treatment of heart failure [142] and opebacan, Xoma 629 (Xoma), and CP-226 (Migenix), which could be used for the treatment of allogeneic stem cells transplantationassociated infections, endotoxemia in haematopoietic stem cells, impetigo, and catheter/dermatology-related infections [127].

3.4. AMPs As Contraceptive Agents for Vaginal Prophylaxis. A number of AMPs have been described in the reproductive tract of mammals that serves dual role on regulating fertility and preventing sexually transmitted diseases [143, 144]. Lactoferrin was found to be localized in the vaginal fluid and mucosal plug, which inhibit viral fusion and its subsequent entry by binding and disruption of the microbial membranes under acidic conditions. Cathelicidin was found to be present in mucosal secretions, vaginal secretions, and seminal plasma, which prevented the microbial infections following sexual intercourse by neutralizing the lipopolysaccharides 
of microbial cells. Defensins were reported to be present in ectocervix, vagina, testis, epididymis, seminal plasma, sperm, and germ cells that impair with the metabolic processes of microbes by penetrating the microbial membranes $[145,146]$. Dermaseptins and magainins are two classes of cationic, amphipathic $\alpha$-helical peptides identified in the skin extracts of frogs Phyllomedusa sauvagei and Xenopus laevis, which showed contraceptive activities against various sexually transmitted infections (STIs) causing pathogens and HIV infections [147]. Nisin possessed contraceptive effect by arresting the movement of spermatozoa, whereas magainin Al inhibited the sperm motility without causing damage to vaginal epithelial cells, thereby could be used as novel contraceptive microbicides [148, 149].

3.5. AMPs in Plant Transgenesis. Plants are constantly threatened by pathogenic microorganisms present in the environment. In recent, years, transgenic expression of genes encoding AMPs could help to enhance resistance against a wide range of phytopathogens. AMPs have been reported to be expressed in plant systems such as tobacco, banana, and potato for the production of pharmaceutical peptides and to develop transgenic plants that confer resistance to several plant diseases [17, 150]. The AMPs such as D4E1 [151], esculestin [73], MSI-999 [152], human lactoferrin [153], shiva-1, and SB-37 [154] were successfully expressed in plant systems that developed resistance against plant pathogens. A synthetic substitution analogue of antimicrobial peptide maiganin, MSI-99 imparts enhanced resistance to pathogenic fungi, Aspergillus niger in transgenic potato cultivars [155]. Integration of antimicrobial peptide genes $N p 3$ and $N p 5$ from Chinese shrimp (Fenneropenaeus Chinensis) into the rice plant, Oryza sativa L. subsp. japonica cv. Aichi asahi possessed broad spectrum resistance to rice bacterial blight disease [156]. Expression of a novel antimicrobial peptide penaeidin 4-1 from the shrimp, Litopenaeus setiferus in creeping bent grass, Agrostis stolonifera L. showed enhanced resistance to fungal disease, dollar spot, and brown patch [157]. Thus, the application of AMPs in plant transgenesis seems to be the alternative strategy for plant disease control.

\section{Conclusion}

AMPs are potent agents with diverse structural and antimicrobial properties, which represent one of the most promising future drug candidate for combating infections and microbial drug resistance. In addition to their microbicidal activity, AMPs also possess other biological activities and have potential applications as signalling molecules, immune modulators, antitumour agents, drug delivery vehicles, and plant transgenesis mediators. Thus, understanding the versatile biological properties of AMPs can be of extreme importance for clinical development of peptide-based therapeutics.

\section{Conflict of Interests}

The authors declare that they have no conflict of interests

\section{Acknowledgments}

Muthuirulan Pushpanathan gratefully acknowledges the LADY TATA memorial trust, Mumbai, for providing financial support. Jeyaprakash Rajendhran acknowledges the Department of Science and Technology, New Delhi, for providing financial support under SERC Fast Track Scheme for Young Scientists (no. SR/FT/LS-004/2008). Authors gratefully acknowledge the Department of Biotechnology, New Delhi, for providing financial support (no. BT/PR-10486/ BCE/08/657/2008). Authors also acknowledge the central facilities, CAS, CEGS, NRCBS, DBT-IPLS, DST-CEFC, DSTPURSE at MKU.

\section{References}

[1] M. Zanetti, "Cathelicidins, multifunctional peptides of the innate immunity," Journal of Leukocyte Biology, vol. 75, no. 1, pp. 39-48, 2004.

[2] R. E. W. Hancock and A. Patrzykat, "Clinical development of cationic antimicrobial peptides: from natural to novel antibiotics," Current Drug Targets, vol. 2, no. 1, pp. 79-83, 2002.

[3] R. E. Hancock, "Cationic peptides: effectors in innate immunity and novel antimicrobials," Lancet Infectious Diseases, vol. 1, no. 3, pp. 156-164, 2001.

[4] J. Nissen-Meyer and I. F. Nes, "Ribosomally synthesized antimicrobial peptides: their function, structure, biogenesis, and mechanism of action," Archives of Microbiology, vol. 167, no. 2-3, pp. 67-77, 1997.

[5] K. Matsuzaki, "Why and how are peptide-lipid interactions utilized for self-defense? Magainins and tachyplesins as archetypes," Biochimica et Biophysica Acta, vol. 1462, no. 1-2, pp. 1-10, 1999.

[6] R. E. W. Hancock, K. L. Brown, and N. Mookherjee, "Host defence peptides from invertebrates-emerging antimicrobial strategies," Immunobiology, vol. 211, no. 4, pp. 315-322, 2006.

[7] K. A. Brogden, "Antimicrobial peptides: pore formers or metabolic inhibitors in bacteria?" Nature Reviews Microbiology, vol. 3, no. 3, pp. 238-250, 2005.

[8] W. Kamysz, M. Okrój, and J. Łukasiak, "Novel properties of antimicrobial peptides," Acta Biochimica Polonica, vol. 50, no. 2, pp. 461-469, 2003.

[9] P. Bulet, C. Hetru, J.-L. Dimarcq, and D. Hoffmann, "Antimicrobial peptides in insects; structure and function," Developmental and Comparative Immunology, vol. 23, no. 4-5, pp. 329-344, 1999.

[10] P. Bulet and R. Stöcklin, "Insect antimicrobial peptides: structures, properties and gene regulation," Protein and Peptide Letters, vol. 12, no. 1, pp. 3-11, 2005.

[11] A. C. Rinaldi, "Antimicrobial peptides from amphibian skin: an expanding scenario," Current Opinion in Chemical Biology, vol. 6, no. 6, pp. 799-804, 2002.

[12] C. Li, T. Haug, and K. Stensvåg, "Antimicrobial peptides in Echinoderms," Invertebrate Survival Journal, vol. 7, pp. 132-140, 2010.

[13] R. D. Rosa and M. A. Barraco, "Antimicrobial peptides in crustaceans," Invertebrate Survival Journal, pp. 262-284, 2010.

[14] M. S. Castro and W. Fontes, "Plant defense and antimicrobial peptides," Protein and Peptide Letters, vol. 12, no. 1, pp. 13-18, 2005. 
[15] H. Jenssen, P. Hamill, and R. E. W. Hancock, "Peptide antimicrobial agents," Clinical Microbiology Reviews, vol. 19, no. 3, pp. 491-511, 2006.

[16] K. N. Sorensen, A. A. Wanstrom, S. D. Allen, and J. Y. Takemoto, "Efficacy of Syringomycin E in a murine model of vaginal candidiasis," Journal of Antibiotics, vol. 51, no. 8, pp. 743-749, 1998.

[17] M. F. C. De Bolle, R. W. Osborn, I. J. Goderis et al., "Antimicrobial peptides from Mirabilis jalapa and Amaranthus caudatus: expression, processing, localization and biological activity in transgenic tobacco," Plant Molecular Biology, vol. 31, no. 5, pp. 993-1008, 1996.

[18] S. Ravichandran, K. Kumaravel, G. Rameshkumar, and T. T. Ajithkumar, "Antimicrobial peptides from the marine fishes," Research Journal of Immunology, vol. 3, no. 2, pp. 146-156, 2010.

[19] L. Silvestro, K. Gupta, J. N. Weiser, and P. H. Axelsen, "The concentration-dependent membrane activity of Cecropin A," Biochemistry, vol. 36-38, pp. 11452-11460, 1999.

[20] C. Landon, P. Sodano, C. Hetru, J. Hoffmann, and M. Ptak, "Solution structure of drosomycin, the first inducible antifungal protein from insects," Protein Science, vol. 6, no. 9, pp. 18781884, 1997.

[21] M. Ohta, H. Ito, K. Masuda et al., "Mechanisms of antibacterial action of tachyplesins and polyphemusins, a group of antimicrobial peptides isolated from horseshoe crab hemocytes," Antimicrobial Agents and Chemotherapy, vol. 36, no. 7, pp. 14601465, 1992.

[22] D. Destoumieux, M. Munoz, P. Bulet, and E. Bachère, "Penaeidins, a family of antimicrobial peptides from penaeid shrimp (Crunstacea, Decapoda)," Cellular and Molecular Life Sciences, vol. 57, no. 8-9, pp. 1260-1271, 2000.

[23] G. Kragol, S. Lovas, G. Varadi, B. A. Condie, R. Hoffmann, and L. Otvos Jr., "The antibacterial peptide pyrrhocoricin inhibits the ATPase actions of DnaK and prevents chaperone-assisted protein folding," Biochemistry, vol. 40, no. 10, pp. 3016-3026, 2001.

[24] M. Hedengren, K. Borge, and D. Hultmark, "Expression and evolution of the Drosophila Attacin/Diptericin gene family," Biochemical and Biophysical Research Communications, vol. 279, no. 2, pp. 574-581, 2000.

[25] F. G. Oppenheim, D. I. Hay, D. J. Smith, G. D. Offner, and R. F. Troxler, "Molecular basis of salivary proline-rich protein and peptide synthesis: cell-free translations and processing of human and macaque statherin mRNAs and partial amino acid sequence of their signal peptides," Journal of Dental Research, vol. 66, no. 2, pp. 462-466, 1987.

[26] C. L. Friedrich, A. Rozek, A. Patrzykat, and R. E. W. Hancock, "Structure and mechanism of action of an indolicidin peptide derivative with improved activity against Gram-positive bacteria," Journal of Biological Chemistry, vol. 276, no. 26, pp. 2401524022, 2001.

[27] J.-M. Strub, P. Garcia-Sablone, K. Lonning et al., "Processing of chromogranin B in bovine adrenal medulla. Identification of secretolytin, the endogenous $\mathrm{C}$-terminal fragment of residues 614-626 with antibacterial activity," European Journal of Biochemistry, vol. 229, no. 2, pp. 356-368, 1995.

[28] B. Schittek, R. Hipfel, B. Sauer et al., "Dermcidin: a novel human antibiotic peptide secreted by sweat glands," Nature Immunology, vol. 2, no. 12, pp. 1133-1137, 2001.

[29] J. Y. Leem, I. J. Jeong, K. T. Park, and H. Y. Park, "Isolation of phydroxycinnamaldehyde as an antibacterial substance from the saw fly, Acantholyda parki S," FEBS Letters, vol. 442, no. 1, pp. 53-56, 1999.

[30] P. M. Hwang, N. Zhou, X. Shan, C. H. Arrowsmith, and H. J. Vogel, "Three-dimensional solution structure of lactoferricin B, an antimicrobial peptide derived from bovine lactoferrin," Biochemistry, vol. 37, pp. 4288-4298, 1998.

[31] M. Zasloff, "Antimicrobial peptides of multicellular organisms," Nature, vol. 415, no. 6870, pp. 389-395, 2002.

[32] N. Y. Yount and M. R. Yeaman, "Multidimensional signatures in antimicrobial peptides," Proceedings of the National Academy of Sciences of the United States of America, vol. 101, no. 19, pp. 7363-7368, 2004.

[33] J. Herbinière, C. Braquart-Varnier, P. Grève et al., "Armadillidin: a novel glycine-rich antibacterial peptide directed against grampositive bacteria in the woodlouse Armadillidium vulgare (Terrestrial Isopod, Crustacean)," Developmental and Comparative Immunology, vol. 29, no. 6, pp. 489-499, 2005.

[34] A. Tassanakajon, P. Amparyup, K. Somboonwiwat, and P. Supungul, "Cationic antimicrobial peptides in penaeid shrimp," Marine Biotechnology, vol. 12, no. 5, pp. 487-505, 2010.

[35] S. Ranganathan, K. J. Simpson, D. C. Shaw, and K. R. Nicholas, "The whey acidic protein family: a new signature motif and three-dimensional structure by comparative modeling," Journal of Molecular Graphics and Modelling, vol. 17, no. 2, pp. 106-113, 1999.

[36] J. P. Tam, Y.-A. Lu, J.-L. Yang, and K.-W. Chiu, “An unusual structural motif of antimicrobial peptides containing end-toend macrocycle and cystine-knot disulfides," Proceedings of the National Academy of Sciences of the United States of America, vol. 96, no. 16, pp. 8913-8918, 1999.

[37] E. Andersson, V. Rydengård, A. Sonesson, M. Mörgelin, L. Björck, and A. Schmidtchen, "Antimicrobial activities of heparin-binding peptides," European Journal of Biochemistry, vol. 271, no. 6, pp. 1219-1226, 2004.

[38] M. Pushpanathan, J. Rajendhran, S. Jayashree, B. Sundarakrishnan, S. Jayachandran, and P. Gunasekaran, "Identification of a novel antifungal peptide with chitin-binding property from marine metagenome," Protein and Peptide Letters, vol. 19, pp. 1289-1296, 2012.

[39] T. Osaki, M. Omotezako, R. Nagayama et al., "Horseshoe crab hemocyte-derived antimicrobial polypeptides, tachystatins, with sequence similarity to spider neurotoxins," Journal of Biological Chemistry, vol. 274, no. 37, pp. 26172-26178, 1999.

[40] K. H. Lee, S. Y. Hong, and J. E. Oh, "Synthesis and structurefunction study about tenecin 1, an antibacterial protein from larvae of Tenebrio molitor," FEBS Letters, vol. 439, no. 1-2, pp. 41-45, 1998.

[41] P. Fehlbaum, P. Bulet, S. Chernysh et al., "Structure-activity analysis of thanatin, a 21-residue inducible insect defense peptide with sequence homology to frog skin antimicrobial peptides," Proceedings of the National Academy of Sciences of the United States of America, vol. 93, no. 3, pp. 1221-1225, 1996.

[42] P. Guterstam, F. Madani, H. Hirose et al., "Elucidating cellpenetrating peptide mechanisms of action for membrane interaction, cellular uptake, and translocation utilizing the hydrophobic counter-anion pyrenebutyrate," Biochimica et Biophysica Acta, vol. 1788, no. 12, pp. 2509-2517, 2009.

[43] M. Pushpanathan, J. Rajendhran, S. Jayashree, B. Sundarakrishnan, S. Jayachandran, and P. Gunasekaran, "Direct cell penetration of antifungal peptide, MMGP1 in Candida albicans," Journal of Peptide Science, vol. 18, pp. 657-660, 2012. 
[44] C. B. Park, K.-S. Yi, K. Matsuzaki, M. S. Kim, and S. C. Kim, "Structure-activity analysis of buforin II, a histone H2A-derived antimicrobial peptide: the proline hinge is responsible for the cell-penetrating ability of buforin II," Proceedings of the National Academy of Sciences of the United States of America, vol. 97, no. 15, pp. 8245-8250, 2000.

[45] H.-Y. Li, "Antifungal metabolites from marine sponges," Current Organic Chemistry, vol. 2, no. 6, pp. 649-682, 1998.

[46] V. R. Scott, R. Boehme, and T. R. Matthews, "New class of antifungal agents: jasplakinolide, a cyclodepsipeptide from the marine sponge, Jaspis species," Antimicrobial Agents and Chemotherapy, vol. 32, no. 8, pp. 1154-1157, 1988.

[47] D. P. Clark, J. Carroll, S. Naylor, and P. Crews, "An antifungal cyclodepsipeptide, cyclolithistide A, from the sponge Theonella swinhoei," Journal of Organic Chemistry, vol. 63, no. 24, pp. 8757-8764, 1998.

[48] C. A. Bewley, C. Debitus, and D. J. Faulkner, "Microsclerodermins A and B. Antifungal cyclic peptides from the lithistid sponge Microscleroderma sp," Journal of the American Chemical Society, vol. 116, no. 17, pp. 7631-7636, 1994.

[49] A. Zampella, M. V. D’Auria, L. Gomez Paloma et al., "Callipeltin A, an anti-HIV cyclic depsipeptide from the new Caledonian lithistida sponge Callipelta sp," Journal of the American Chemical Society, vol. 118, no. 26, pp. 6202-6209, 1996.

[50] D. J. Milanowski, K. R. Gustafson, M. A. Rashid, L. K. Pannell, J. B. McMahon, and M. R. Boyd, "Gymnangiamide, a cytotoxic pentapeptide from the marine hydroid Gymnangium regae," Journal of Organic Chemistry, vol. 69, no. 9, pp. 3036-3042, 2004.

[51] S. M. Asaduzzaman, J.-I. Nagao, H. Iida, T. Zendo, J. Nakayama, and K. Sonomoto, "Nukacin ISK-1, a bacteriostatic lantibiotic," Antimicrobial Agents and Chemotherapy, vol. 53, no. 8, pp. 35953598, 2009.

[52] H. Brötz, G. Bierbaum, P. E. Reynolds, and H.-G. Sahl, “The lantibiotic mersacidin inhibits peptidoglycan biosynthesis at the level of transglycosylation," European Journal of Biochemistry, vol. 246, no. 1, pp. 193-199, 1997.

[53] F. Castiglione, A. Lazzarini, L. Carrano et al., "Determining the structure and mode of action of microbisporicin, a potent lantibiotic active against multiresistant pathogens," Chemistry and Biology, vol. 15, no. 1, pp. 22-31, 2008.

[54] J.-C. Piard, P. M. Muriana, M. J. Desmazeaud, and T. R. Klaenhammer, "Purification and partial characterization of lacticin 481, a lanthionine- containing bacteriocin produced by Lactococcus lactis subsp. lactis CNRZ 481," Applied and Environmental Microbiology, vol. 58, no. 1, pp. 279-284, 1992.

[55] S. Y. Shin, S.-H. Lee, S.-T. Yang et al., "Antibacterial, antitumor and hemolytic activities of $\alpha$-helical antibiotic peptide, P18 and its analogs," Journal of Peptide Research, vol. 58, no. 6, pp. 504514, 2001.

[56] M. Pasupuleti, A. Schmidtchen, A. Chalupka, L. Ringstad, and M. Malmsten, "End-tagging of ultra-short antimicrobial peptides by W/F stretches to facilitate bacterial killing," PLOS ONE, vol. 4, no. 4, Article ID e5285, 2009.

[57] H. Jenssen, C. D. Fjell, A. Cherkasov, and R. E. W. Hancock, "QSAR modeling and computer-aided design of antimicrobial peptides," Journal of Peptide Science, vol. 14, no. 1, pp. 110-114, 2008.

[58] A. Malina and Y. Shai, "Conjugation of fatty acids with different lengths modulates the antibacterial and antifungal activity of a cationic biologically inactive peptide," Biochemical Journal, vol. 390, no. 3, pp. 695-702, 2005.
[59] K. Ösapay, D. Tran, A. S. Ladokhin, S. H. White, A. H. Henschen, and M. E. Selsted, "Formation and characterization of a single Trp-Trp cross-link in indolicidin that confers protease stability without altering antimicrobial activity," Journal of Biological Chemistry, vol. 275, no. 16, pp. 12017-12022, 2000.

[60] A. Rozek, J.-P. S. Powers, C. L. Friedrich, and R. E. W. Hancock, "Structure-based design of an indolicidin peptide analogue with increased protease stability," Biochemistry, vol. 42, no. 48, pp. 14130-14138, 2003.

[61] N. Fusetani, "Antifungal peptides in marine invertebrates," Invertebrate Survival Journal, vol. 7, pp. 53-66, 2010.

[62] C. Van Kraaij, W. M. De Vos, R. J. Siezen, and O. P. Kuipers, "Lantibiotics: biosynthesis, mode of action and applications," Natural Product Reports, vol. 16, no. 5, pp. 575-587, 1999.

[63] M. S. P. Sansom, "Peptides and lipid bilayers: dynamic interactions," Current Opinion in Colloid and Interface Science, vol. 3, no. 5, pp. 518-524, 1998.

[64] D. Dolis, C. Moreau, A. Zachowski, and P. F. Devaux, "Aminophospholipid translocase and proteins involved in transmembrane phospholipid traffic," Biophysical Chemistry, vol. 68, no. 1-3, pp. 221-231, 1997.

[65] L. H. Kondejewski, M. Jelokhani-Niaraki, S. W. Farmer et al., "Dissociation of antimicrobial and hemolytic activities in cyclic peptide diastereomers by systematic alterations in amphipathicity," Journal of Biological Chemistry, vol. 274, no. 19, pp. 1318113192, 1999.

[66] J. Patterson-Delafield, R. J. Martinez, and R. I. Lehrer, "Microbicidal cationic proteins in rabbit alveolar macrophages: a potential host defense mechanism," Infection and Immunity, vol. 30, no. 1, pp. 180-192, 1980.

[67] L. Yang, T. A. Harroun, T. M. Weiss, L. Ding, and H. W. Huang, "Barrel-stave model or toroidal model? A case study on melittin pores," Biophysical Journal, vol. 81, no. 3, pp. 1475-1485, 2001.

[68] K. J. Hallock, D.-K. Lee, and A. Ramamoorthy, "MSI-78, an analogue of the magainin antimicrobial peptides, disrupts lipid bilayer structure via positive curvature strain," Biophysical Journal, vol. 84, no. 5, pp. 3052-3060, 2003.

[69] K. A. Henzler Wildman, D.-K. Lee, and A. Ramamoorthy, "Mechanism of lipid bilayer disruption by the human antimicrobial peptide, LL-37," Biochemistry, vol. 42, no. 21, pp. 65456558, 2003.

[70] A. Patrzykat, C. L. Friedrich, L. Zhang, V. Mendoza, and R. E. W. Hancock, "Sublethal concentrations of pleurocidin-derived antimicrobial peptides inhibit macromolecular synthesis in Escherichia coli," Antimicrobial Agents and Chemotherapy, vol. 46, no. 3, pp. 605-614, 2002.

[71] M. K. Lee, L. Cha, S. H. Lee, and K.-S. Hahm, "Role of amino acid residues within the disulfide loop of thanatin, a potent antibiotic peptide," Journal of Biochemistry and Molecular Biology, vol. 35, no. 3, pp. 291-296, 2002.

[72] B. Hwang, J.-S. Hwang, J. Lee et al., "Induction of yeast apoptosis by an antimicrobial peptide, Papiliocin," Biochemical and Biophysical Research Communications, vol. 408, no. 1, pp. 89-93, 2011.

[73] C. Park and D. G. Lee, "Melittin induces apoptotic features in Candida albicans," Biochemical and Biophysical Research Communications, vol. 394, no. 1, pp. 170-172, 2010.

[74] K. Kavanagh and S. Dowd, "Histatins: antimicrobial peptides with therapeutic potential," Journal of Pharmacy and Pharmacology, vol. 56, no. 3, pp. 285-289, 2004. 
[75] K. Lohner and E. J. Prenner, "Differential scanning calorimetry and X-ray diffraction studies of the specificity of the interaction of antimicrobial peptides with membrane- mimetic systems," Biochimica et Biophysica Acta, vol. 1462, no. 1-2, pp. 141-156, 1999.

[76] I. Ben-Efraim and Y. Shai, "The structure and organization of synthetic putative membranous segments of ROMK1 channel in phospholipid membranes," Biophysical Journal, vol. 72, no. 1, pp. 85-96, 1997.

[77] K. He, S. J. Ludtke, D. L. Worcester, and H. W. Huang, "Neutron scattering in the plane of membranes: structure of alamethicin pores," Biophysical Journal, vol. 70, no. 6, pp. 2659-2666, 1996.

[78] L. Zhang, A. Rozek, and R. E. W. Hancock, "Interaction of cationic antimicrobial peptides with model membranes," Journal of Biological Chemistry, vol. 276, no. 38, pp. 35714-35722, 2001.

[79] Z. Oren and Y. Shai, "Mode of action of linear amphipathic $\alpha$ helical antimicrobial peptides," Biopolymers, vol. 47, no. 6, pp. 451-463, 1998.

[80] D. Sengupta, H. Leontiadou, A. E. Mark, and S.-J. Marrink, "Toroidal pores formed by antimicrobial peptides show significant disorder," Biochimica et Biophysica Acta, vol. 1778, no. 10, pp. 2308-2317, 2008.

[81] F. Madani, S. Lindberg, Ü. Langel, S. Futaki, and A. Gräslund, "Mechanisms of cellular uptake of cell-penetrating peptides," Journal of Biophysics, vol. 2011, Article ID 414729, 10 pages, 2011.

[82] S. T. Henriques, M. N. Melo, and M. A. R. B. Castanho, "Cellpenetrating peptides and antimicrobial peptides: how different are they?" Biochemical Journal, vol. 399, no. 1, pp. 1-7, 2006.

[83] P. Järver and Ü. Langel, "Cell-penetrating peptides-a brief introduction," Biochimica et Biophysica Acta, vol. 1758, no. 3, pp. 260-263, 2006.

[84] X. Zhang, K. Oglęcka, S. Sandgren et al., "Dual functions of the human antimicrobial peptide LL-37-Target membrane perturbation and host cell cargo delivery," Biochimica et Biophysica Acta, vol. 1798, no. 12, pp. 2201-2208, 2010.

[85] N. Nekhotiaeva, A. Elmquist, G. K. Rajarao, M. Hällbrink, U. Langel, and L. Good, "Cell entry and antimicrobial properties of eukaryotic cell-penetrating peptides," The FASEB Journal, vol. 18, no. 2, pp. 394-396, 2004.

[86] K. Takeshima, A. Chikushi, K.-K. Lee, S. Yonehara, and K. Matsuzaki, "Translocation of analogues of the antimicrobial peptides magainin and buforin across human cell membranes," Journal of Biological Chemistry, vol. 278, no. 2, pp. 1310-1315, 2003.

[87] J. Temsamani and C. Laruelle, "SynB peptide vectors a new approach to drug delivery," Chimica Oggi, vol. 28, no. 1, pp. 1820, 2010.

[88] L. Otvos Jr., "Antibacterial peptides isolated from insects," Journal of Peptide Science, vol. 6, pp. 497-511, 2000.

[89] K. Sadler, K. D. Eom, J.-L. Yang, Y. Dimitrova, and J. P. Tam, "Translocating proline-rich peptides from the antimicrobial peptide bactenecin 7," Biochemistry, vol. 41, no. 48, pp. 1415014157, 2002.

[90] K. Splith and I. Neundorf, "Antimicrobial peptides with cellpenetrating peptide properties and vice versa," European Biophysics Journal, vol. 40, no. 4, pp. 387-397, 2011.

[91] S. P. Wu, T. C. Huang, C. C. Lin, C. F. Hui, C. H. Lin, and J. Y. Chen, "Pardaxin, a fish antimicrobial peptide, exhibits antitumour activity toward fibrosarcoma in vitro and in vivo," Marine Drugs, vol. 10, pp. 1852-1872, 2012.
[92] H. van Zoggel, G. Carpentier, C. Dos Santos et al., "Antitumor and angiostatic activities of the antimicrobial peptide dermaseptin B2," PLoS ONE, vol. 7, Article ID e44351, 2012.

[93] L. Cruz-Chamorro, M. A. Puertollano, E. Puertollano, G. Á. de Cienfuegos, and M. A. de Pablo, "In vitro biological activities of magainin alone or in combination with nisin," Peptides, vol. 27, no. 6, pp. 1201-1209, 2006.

[94] S. S. Saini, A. K. Chopra, and J. W. Peterson, "Melittin activates endogenous phospholipase D during cytolysis of human monocytic leukemia cells," Toxicon, vol. 37, no. 11, pp. 1605-1619, 1999.

[95] P. J. Russell, D. Hewish, T. Carter et al., "Cytotoxic properties of immunoconjugates containing melittin-like peptide 101 against prostate cancer: in vitro and in vivo studies," Cancer Immunology, Immunotherapy, vol. 53, no. 5, pp. 411-421, 2004.

[96] J. Doyle, C. S. Brinkworth, K. L. Wegener et al., "nNOS inhibition, antimicrobial and anticancer activity of the amphibian skin peptide, citropin 1.1 and synthetic modifications: the solution structure of a modified citropin 1.1," European Journal of Biochemistry, vol. 270, no. 6, pp. 1141-1153, 2003.

[97] Y. R. Chan and R. L. Gallo, "PR-39, a syndecan-inducing antimicrobial peptide, binds and affects p130(Cas)," Journal of Biological Chemistry, vol. 273, no. 44, pp. 28978-28985, 1998.

[98] L. Hui, K. Leung, and H. M. Chen, "The combined effects of antibacterial peptide cecropin $\mathrm{A}$ and anti-cancer agents on leukemia cells," Anticancer Research, vol. 22, no. 5, pp. 2811-2816, 2002.

[99] D. Winder, W. H. Günzburg, V. Erfle, and B. Salmons, "Expression of antimicrobial peptides has an antitumour effect in human cells," Biochemical and Biophysical Research Communications, vol. 242, no. 3, pp. 608-612, 1998.

[100] A. J. Moore, D. A. Devine, and M. C. Bibby, "Preliminary experimental anticancer activity of cecropins," Peptide Research, vol. 7, no. 5, pp. 265-269, 1994.

[101] H. Suttmann, M. Retz, F. Paulsen et al., "Antimicrobial peptides of the Cecropin-family show potent antitumor activity against bladder cancer cells," BMC Urology, vol. 8, no. 1, article 5, 2008.

[102] A. Risso, E. Braidot, M. C. Sordano et al., "BMAP-28, an antibiotic peptide of innate immunity, induces cell death through opening of the mitochondrial permeability transition pore," Molecular and Cellular Biology, vol. 22, no. 6, pp. 19261935, 2002.

[103] A. K. Lichtenstein, T. Ganz, T.-M. Nguyen, M. E. Selsted, and R. I. Lehrer, "Mechanism of target cytolysis by peptide defensins. Target cell metabolic activities, possibly involving endocytosis, are crucial for expression of cytotoxicity," Journal of Immunology, vol. 140, no. 8, pp. 2686-2694, 1988.

[104] S. T. W. McKeown, F. T. Lundy, J. Nelson et al., "The cytotoxic effects of human neutrophil peptide-1 (HNP1) and lactoferrin on oral squamous cell carcinoma (OSCC) in vitro," Oral Oncology, vol. 42, no. 7, pp. 685-690, 2006.

[105] Y.-C. Yoo, R. Watanabe, Y. Koike et al., "Apoptosis in human leukemic cells induced by lactoferricin, a bovine milk proteindevived peptide: involvement of reactive oxygen species," Biochemical and Biophysical Research Communications, vol. 237, no. 3, pp. 624-628, 1997.

[106] J. S. Mader, D. Smyth, J. Marshall, and D. W. Hoskin, "Bovine lactoferricin inhibits basic fibroblast growth factor- and vascular endothelial growth factor165-induced angiogenesis by competing for heparin-like binding sites on endothelial cells," American Journal of Pathology, vol. 169, no. 5, pp. 1753-1766, 2006. 
[107] T. Nakamura, H. Furunaka, T. Miyata et al., “Tachyplesin, a class of antimicrobial peptide from the hemocytes of the horseshoe crab (Tachypleus tridentatus). Isolation and chemical structure," Journal of Biological Chemistry, vol. 263, no. 32, pp. 16709-16713, 1988.

[108] T. Ohtake, Y. Fujimoto, K. Ikuta et al., "Proline rich antimicrobial peptide, PR-39 gene transduction altered invasive activity and actin structure in human hepatocellular carcinoma cells," British Journal of Cancer, vol. 81, no. 3, pp. 393-403, 1999.

[109] S. Y. Shin, M. K. Lee, K. L. Kim, and K.-S. Hahm, "Structureantitumor and hemolytic activity relationships of synthetic peptides derived from cecropin A-magainin 2 and cecropin Amelittin hybrid peptides," Journal of Peptide Research, vol. 50, no. 4, pp. 279-285, 1997.

[110] T. Utsugi, A. J. Schroit, J. Connor, C. D. Bucana, and I. J. Fidler, "Elevated expression of phosphatidylserine in the outer membrane leaflet of human tumor cells and recognition by activated human blood monocytes," Cancer Research, vol. 51, no. 11, pp. 3062-3066, 1991.

[111] L. Jacob and M. Zasloff, "Potential therapeutic applications of magainins and other antimicrobial agents of animal origin," Ciba Foundation Symposium, vol. 186, pp. 197-216, 1994.

[112] A. Lichtenstein, T. Ganz, M. E. Selsted, and R. I. Lehrer, "In vitro tumor cell cytolysis mediated by peptide defensins of human and rabbit granulocytes," Blood, vol. 68, no. 6, pp. 1407-1410, 1986.

[113] A. Risso, M. Zanetti, and R. Gennaro, "Cytotoxicity and apoptosis mediated by two peptides of innate immunity," Cellular Immunology, vol. 189, no. 2, pp. 107-115, 1998.

[114] H.-S. Won, M.-D. Seo, S.-J. Jung et al., "Structural determinants for the membrane interaction of novel bioactive undecapeptides derived from gaegurin 5," Journal of Medicinal Chemistry, vol. 49, no. 16, pp. 4886-4895, 2006.

[115] J. Chen, X.-M. Xu, C. B. Underhill et al., "Tachyplesin activates the classic complement pathway to kill tumor cells," Cancer Research, vol. 65, no. 11, pp. 4614-4622, 2005.

[116] S. Liu, H. Yang, L. Wan, J. Cheng, and X. Lu, "Penetratin-mediated delivery enhances the antitumor activity of the cationic antimicrobial peptide magainin II," Cancer Biotherapy \& Radiopharmaceuticals, 2013.

[117] C. A. Müller, J. Markovic-Lipkovski, T. Klatt et al., "Human $\alpha$ defensins HNPs-1, -2 , and -3 in renal cell carcinoma: influences on tumor cell proliferation," American Journal of Pathology, vol. 160, no. 4, pp. 1311-1324, 2002.

[118] M. C. Lin, C. F. Hui, J. H. Chen, and J. L. Wua, "Truncated antimicrobial peptides from marine organisms retains anticancer activity and antibacterial activity against multidrug," Peptides, vol. 44, pp. 139-148, 2013.

[119] C. Rosés, D. Carbajo, G. Sanclimens et al., "Cell-penetrating $\gamma$ peptide/antimicrobial undecapeptide conjugates with anticancer activity," Tetrahedron, vol. 68, pp. 4406-4412, 2012.

[120] P. Koszałka, E. Kamysz, M. Wejda, W. Kamysz, and J. Bigda, "Antitumor activity of antimicrobial peptides against U937 histiocytic cell line," Acta Biochimica Polonica, vol. 58, no. 1, pp. 111-117, 2011.

[121] P. A. Charp, W. G. Rice, R. L. Raynor et al., "Inhibition of protein kinase C by defensins, antibiotic peptides from human neutrophils," Biochemical Pharmacology, vol. 37, no. 5, pp. 951-956, 1988.

[122] K. W. Bensch, M. Raida, H.-J. Magert, P. Schulz-Knappe, and W.-G. Forssmann, "hBD-1: a novel $\beta$-defensin from human plasma," FEBS Letters, vol. 368, no. 2, pp. 331-335, 1995.
[123] Y. J. Gordon, E. G. Romanowski, R. M. Q. Shanks, K. A. Yates, H. Hinsley, and H. A. Pereira, "CAP37-derived antimicrobial peptides have in vitro antiviral activity against adenovirus and herpes simplex virus type 1," Current Eye Research, vol. 34, no. 3, pp. 241-249, 2009.

[124] I. Li, M. Post, R. Volk et al., "PR39, a peptide regulator of angiogenesis," Nature Medicine, vol. 6, pp. 49-55, 2000.

[125] K. Tanaka, Y. Fujimoto, M. Suzuki et al., "PI3-kinase $\mathrm{p} 85 \alpha$ is a target molecule of proline-rich antimicrobial peptide to suppress proliferation of ras-transformed cells," Japanese Journal of Cancer Research, vol. 92, no. 9, pp. 959-967, 2001.

[126] A. Hobta, I. Lisovskiy, S. Mikhalap et al., "Epidermoid carcinoma-derived antimicrobial peptide (ECAP) inhibits phosphorylation by protein kinases in vitro," Cell Biochemistry and Function, vol. 19, no. 4, pp. 291-298, 2001.

[127] L. Steinstraesser, U. Kraneburg, F. Jacobsen, and S. Al-Benna, "Host defense peptides and their antimicrobial-immunomodulatory duality," Immunobiology, vol. 216, no. 3, pp. 322-333, 2011.

[128] M. Pietiäinen, M. Gardemeister, M. Mecklin, S. Leskelä, M. Sarvas, and V. P. Kontinen, "Cationic antimicrobial peptides elicit a complex stress response in Bacillus subtilis that involves ECFtype sigma factors and two-component signal transduction systems," Microbiology, vol. 151, no. 5, pp. 1577-1592, 2005.

[129] M. Blomqvist, J. Bergquist, A. Westman et al., "Identification of defensins in human lymphocyte nuclei," European Journal of Biochemistry, vol. 263, no. 2, pp. 312-318, 1999.

[130] O. Chertov, D. F. Michiel, L. Xu et al., "Identification of defensin1, defensin-2, and CAP37/azurocidin as T-cell chemoattractant proteins released from interleukin-8-stimulated neutrophils," Journal of Biological Chemistry, vol. 271, no. 6, pp. 2935-2940, 1996.

[131] T. R. Hata and R. L. Gallo, "Antimicrobial peptides, skin infections, and atopic dermatitis," Seminars in Cutaneous Medicine and Surgery, vol. 27, no. 2, pp. 144-150, 2008.

[132] S. Van Wetering, S. P. G. Mannesse-Lazeroms, M. A. J. A. Van Sterkenburg, M. R. Daha, J. H. Dijkman, and P. S. Hiemstra, "Effect of defensins on interleukin-8 synthesis in airway epithelial cells," American Journal of Physiology, vol. 272, no. 5, pp. L888-L896, 1997.

[133] T. W. L. Groeneveld, T. H. Ramwadhdoebé, L. A. Trouw et al., "Human neutrophil peptide-1 inhibits both the classical and the lectin pathway of complement activation," Molecular Immunology, vol. 44, no. 14, pp. 3608-3614, 2007.

[134] M. Salzet, "Antimicrobial peptides are signaling molecules," Trends in Immunology, vol. 23, no. 6, pp. 283-284, 2002.

[135] K. H. Kirsch, M. Kensinger, H. Hanafusa, and A. August, "A p130Cas tyrosine phosphorylated substrate domain decoy disrupts v-Crk signaling," BMC Cell Biology, vol. 3, article 18, 2002.

[136] V. N. Kokriakov, L. V. Koval'chuk, G. M. Aleshina, and O. V. Shamova, "Cationic antimicrobial peptides as molecular immunity factors: multi-functionality," Journal of Microbiology Epidemiology and Immunobiology, no. 2, pp. 98-105, 2006.

[137] J. D. Heimann, “The extracytoplasmic function (ECF) sigma factors," Advances in Microbial Physiology, vol. 46, pp. 47-110, 2002.

[138] P. D. Thackray and A. Moir, "SigM, an extracytoplasmic function sigma factor of Bacillus subtilis, is activated in response to cell wall antibiotics, ethanol, heat, acid, and superoxide stress," Journal of Bacteriology, vol. 185, no. 12, pp. 3491-3498, 2003. 
[139] M. J. Horsburgh and A. Moir, “ $\sigma(\mathrm{M})$, an ECF RNA polymerase sigma factor of Bacillus subtilis 168, is essential for growth and survival in high concentrations of salt," Molecular Microbiology, vol. 32, no. 1, pp. 41-50, 1999.

[140] T. Wiegert, G. Homuth, S. Versteeg, and W. Schumann, "Alkaline shock induces the Bacillus subtilis $\sigma \mathrm{w}$ regulon," Molecular Microbiology, vol. 41, no. 1, pp. 59-71, 2001.

[141] M. Cao, P. A. Kobel, M. M. Morshedi, M. F. W. Wu, C. Paddon, and J. D. Helmann, "Defining the Bacillus subtilis $\sigma \mathrm{W}$ regulon: a comparative analysis of promoter consensus search, runoff transcription/macroarray analysis (ROMA), and transcriptional profiling approaches," Journal of Molecular Biology, vol. 316, no. 3, pp. 443-457, 2002.

[142] R. A. Rose, "CD-NP, a chimeric natriuretic peptide for the treatment of heart failure," Current Opinion in Investigational Drugs, vol. 11, no. 3, pp. 349-356, 2010.

[143] M. Rana, S. Chatterjee, S. Kochhar, and B. M. J. Pereira, "Antimicrobial peptides: a new dawn for regulating fertility and reproductive tract infections," Journal of Endocrinology and Reproduction, vol. 10, pp. 88-95, 2006.

[144] M. Potts, "The urgent need for a vaginal microbicide in the prevention of HIV transmission," American Journal of Public Health, vol. 84, no. 6, pp. 890-891, 1994.

[145] A. M. Cole, "Innate host defense of human vaginal and cervical mucosae," Current Topics in Microbiology and Immunology, vol. 306, pp. 199-230, 2006.

[146] E. Com, F. Bourgeon, B. Evrard et al., "Expression of antimicrobial defensins in the male reproductive tract of rats, mice, and humans," Biology of Reproduction, vol. 68, no. 1, pp. 95-104, 2003.

[147] A. Zairi, F. Tangy, K. Bouassida, and K. Hani, "Dermaseptins and magainins: antimicrobial peptides from frogs' skin-new sources for a promising spermicides microbicides-a mini review," Journal of Biomedicine and Biotechnology, vol. 2009, Article ID 452567, 8 pages, 2009.

[148] G. F. Doncel, "Exploiting common targets in human fertilization and HIV infection: development of novel contraceptive microbicides," Human Reproduction Update, vol. 12, no. 2, pp. 103-117, 2006.

[149] S. M. Gupta, C. C. Aranha, J. R. Bellare, and K. V. R. Reddy, "Interaction of contraceptive antimicrobial peptide nisin with target cell membranes: implications for use as vaginal microbicide," Contraception, vol. 80, no. 3, pp. 299-307, 2009.

[150] D. P. Yevtushenko and S. Misra, "Transgenic expression of antimicrobial peptides in plants: strategies for enhanced disease resistance, improved productivity, and production of therapeutics," ACS Symposium Series, vol. 1095, pp. 445-458, 2012.

[151] J. W. Cary, K. Rajasekaran, J. M. Jaynes, and T. E. Cleveland, "Transgenic expression of a gene encoding a synthetic antimicrobial peptide results in inhibition of fungal growth in vitro and in planta," Plant Science, vol. 154, no. 2, pp. 171-181, 2000.

[152] M. De Grey and T. Justin, "Chloroplast genetic engineering: recent advances and future perspectives," Critical Reviews in Plant Sciences, vol. 24, no. 2, pp. 83-107, 2005.

[153] A. Mitra and Z. Zhang, "Expression of a human lactoferrin cDNA in tobacco cells produces antibacterial protein(s)," Plant Physiology, vol. 106, no. 3, pp. 977-981, 1994.

[154] L. Tripathi, J. N. Tripathi, and W. K. Tushemereirwe, "Strategies for resistance to bacterial wilt disease of bananas through genetic engineering," African Journal of Biotechnology, vol. 3, no. 12, pp. 688-692, 2004.
[155] T. R. Ganapathi, S. B. Ghosh, N. H. S. Laxmi, and V. A. Bapat, "Expression of an antimicrobial peptide (MSI-99) confers enhanced resistance to Aspergillus niger in transgenic potato," Indian Journal of Biotechnology, vol. 6, no. 1, pp. 63-67, 2007.

[156] W. Wang, C. Wu, M. Liu et al., "Resistance of antimicrobial peptide gene transgenic rice to bacterial blight," Rice Science, vol. 18, no. 1, pp. 10-16, 2011.

[157] M. Zhou, Q. Hu, Z. Li, D. Li, C.-F. Chen, and H. Luo, "Expression of a novel antimicrobial peptide Penaeidin4-1 in creeping bentgrass (Agrostis stolonifera L.) enhances plant fungal disease resistance," PLoS ONE, vol. 6, no. 9, Article ID e24677, 2011. 

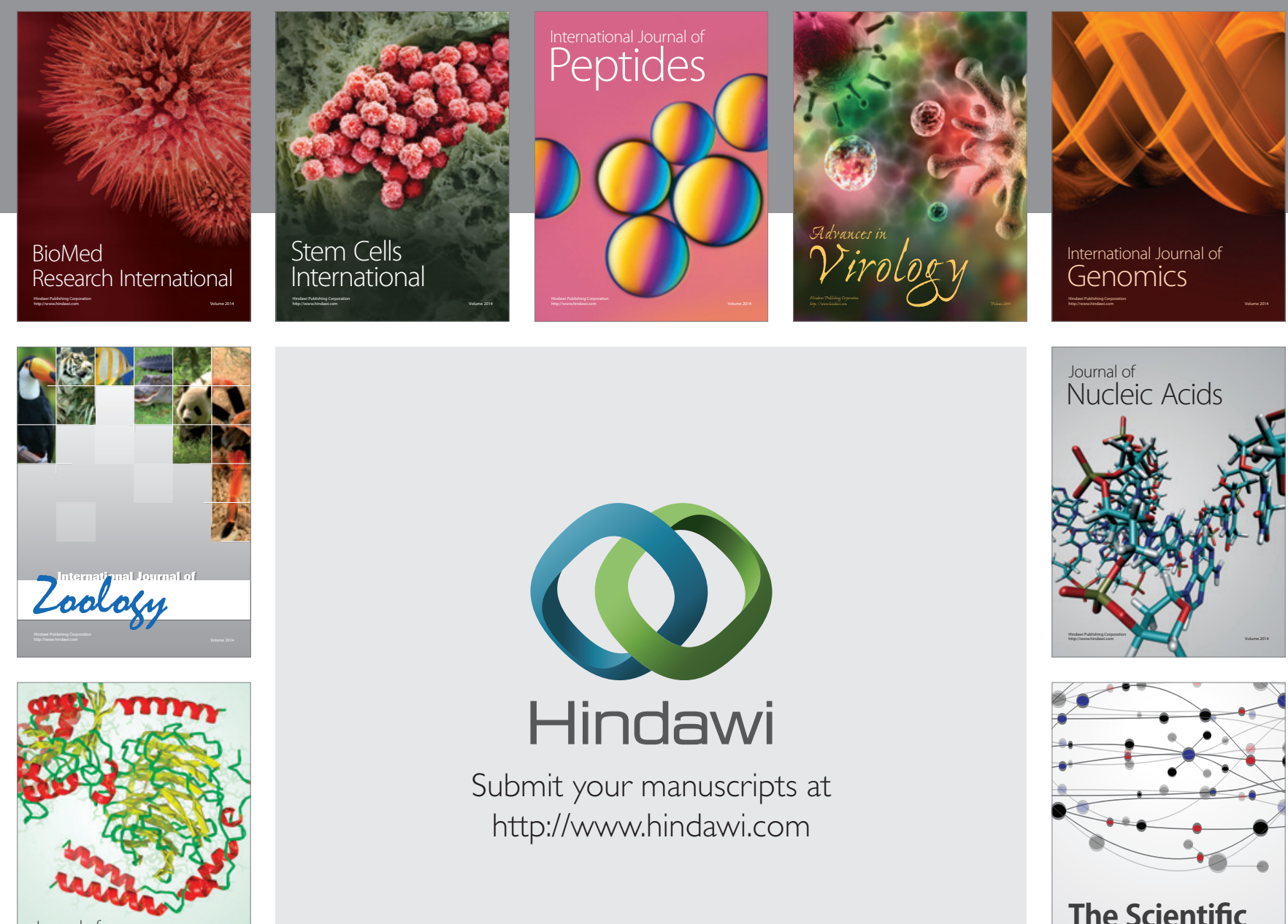

Submit your manuscripts at

http://www.hindawi.com

Journal of
Signal Transduction
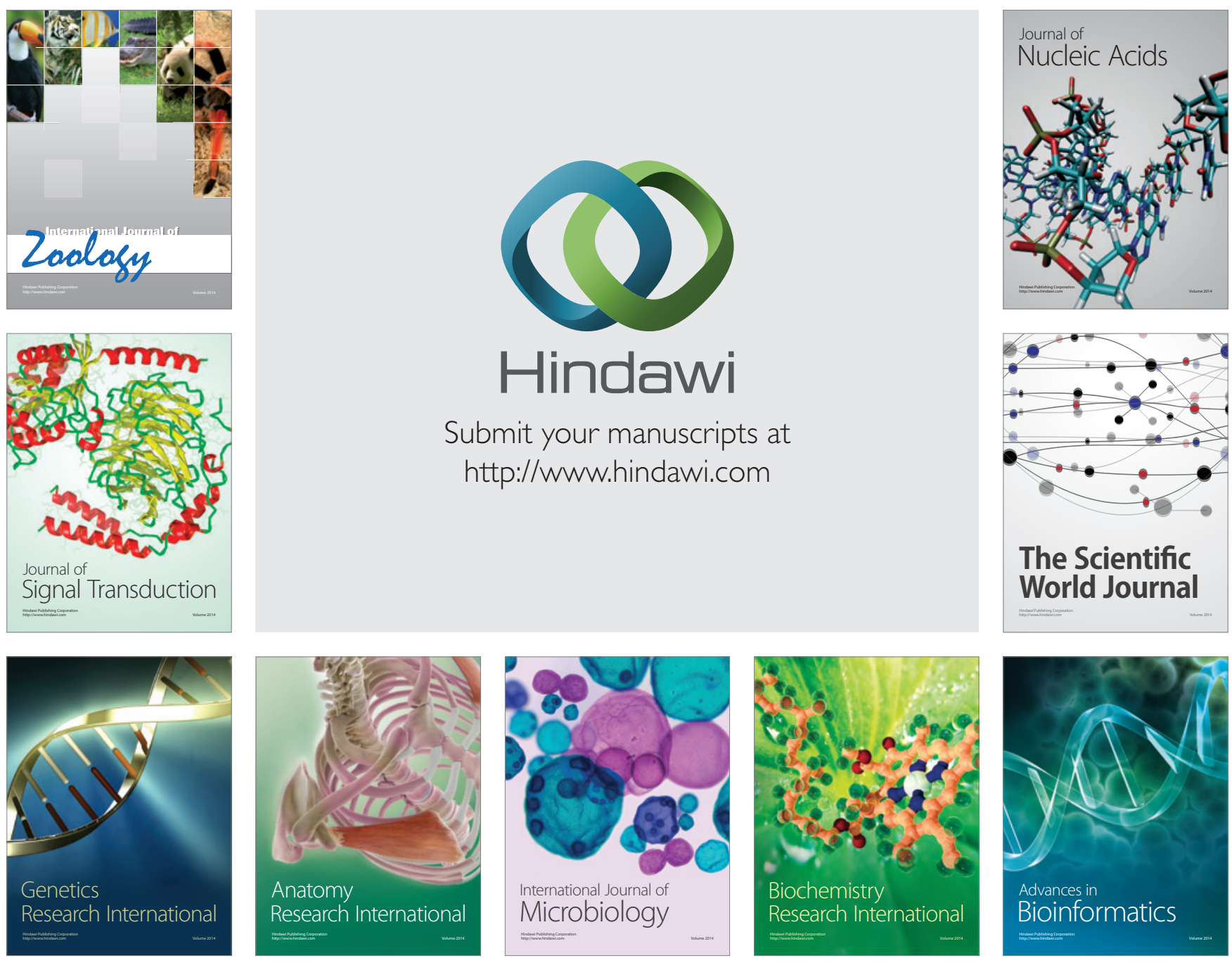

The Scientific World Journal
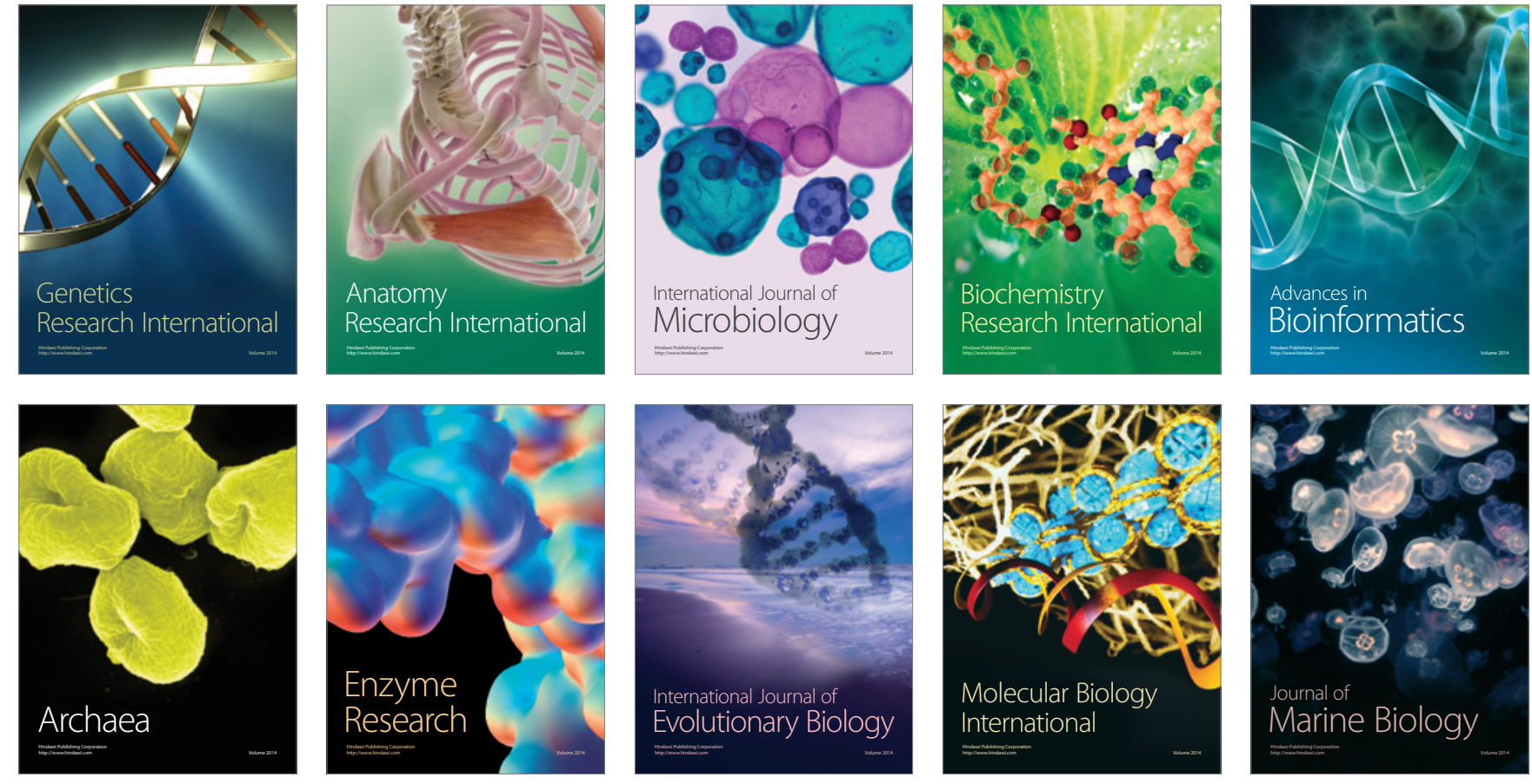